Article

\title{
Mapping Obesogenic Food Environments in South Africa and Ghana: Correlations and Contradictions
}

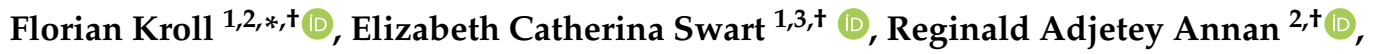

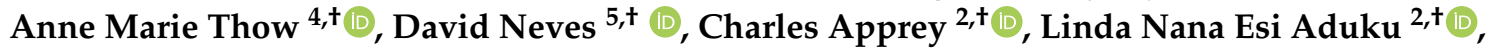

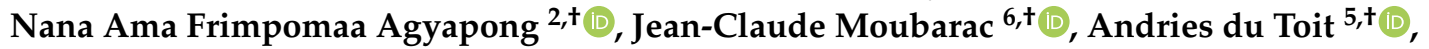 \\ Robert Aidoo $^{7,+}+$ and David Sanders ${ }^{1,+}+\mathbb{D}$ \\ 1 School of Public Health, University of the Western Cape, Cape Town 7535, South Africa \\ 2 Department of Biochemistry and Biotechnology, College of Science, Kwame Nkrumah University of Science and \\ Technology, Private Mail Bag, University Post Office, KNUST, Kumasi 0023351, Ghana \\ 3 Department of Dietetics and Nutrition, University of the Western Cape, Cape Town 7535, South Africa \\ 4 Menzies Centre for Health Policy, University of Sydney, NSW 2006, Australia \\ 5 Institute for Poverty, Land and Agrarian Studies, University of the Western Cape, Cape Town 7535, South Africa \\ 6 Département de Nutrition, Faculté de Médecine, Universi té de Montréal, PO Box 6128, Centre-ville Station \\ Montréal, QC H3C 3J7, Canada \\ 7 Department of Agricultural Economics, Agribusiness \& Extension, Faculty of Agriculture, \\ Kwame Nkrumah University of Science and Technology, Kumasi 0023351, Ghana \\ * Correspondence: florian@plaas.org.za; Tel.: +27-072-501-0756 \\ + These authors contributed equally to this work.
}

Received: 4 April 2019; Accepted: 13 May 2019; Published: 18 July 2019

\begin{abstract}
In sub-Saharan Africa, urbanisation and food systems change contribute to rapid dietary transitions promoting obesity. It is unclear to what extent these changes are mediated by neighbourhood food environments or other factors. This paper correlates neighbourhood food provision with household consumption and poverty in Khayelitsha, South Africa and Ahodwo, Ghana. Georeferenced survey data of food consumption and provision were classified by obesity risk and protection. Outlets were mapped, and density and distribution correlated with risk classes. In Khayelitsha, 71\% of households exceeded dietary obesity risk thresholds while $16 \%$ consumed protective diets. Obesogenic profiles were less $(26 \%)$ and protective more prevalent $(23 \%)$ in Ahodwo despite greater income poverty in Khayelitsha. Here, income-deprived households consumed significantly $(p<0.005)$ less obesogenic and protective diets. Small informal food outlets dominated numerically but supermarkets were key household food sources in Khayelitsha. Although density of food provision in Ahodwo was higher $\left(76 / \mathrm{km}^{2}\right)$, Khayelitsha outlets $\left(61 / \mathrm{km}^{2}\right)$ provided greater access to obesogenic (57\% Khayelitsha; 39\% Ahodwo) and protective (43\% Khayelitsha; $16 \%$ Ahodwo) foods. Consumption and provision profiles correlate more strongly in Ahodwo than Khayelitsha (rKhayelitsha $=0.624$; rAhodwo $=0.862$ ). Higher obesogenic food consumption in Khayelitsha suggests that risky food environments and poverty together promote obesogenic diets.
\end{abstract}

Keywords: obesity; food environments; urban; mapping; nutrition; South Africa; Ghana; governance; supermarkets; ultra-processed 


\section{Introduction}

Urbanisation, poverty, globalisation, industrialisation, climate change and the emergence of a concentrated corporate food regime [1-3] are converging and mutually reinforcing global transitions [4]. Cities in the Global South and their large populations are at the epicentre of these transitions. These have significant implications for sustainability in terms of the health of populations, in terms of the ecosystem disruptions caused by food system activities and in terms of the economic exclusion of large segments of populations from food system activity. Although the United Nations sustainable development goals (UN SDGs 2 and 12) make reference to food security and poverty, they do not recognise the urbanisation of food insecurity nor the dietary transition [5]. This entails increasing consumption of ultra-processed, energy-dense and micronutrient-poor foods, compounded by sedentary lifestyles with reduced physical activity. Consequently, rates of obesity and non-communicable diseases (NCDs) are rising rapidly [6-8]. This shift is particularly severe in low- and middle-income countries (LMICs) and is characterised in some by an increasing "double burden" of simultaneous obesity and persistent childhood stunting [9-11]. Obesity is a major public health concern as it promotes the development of NCDs such as diabetes, hypertension, circulatory disorders and some cancers [12].

This transition has been particularly rapid in Sub-Saharan Africa [13,14], with nutritional change, obesity and NCDs in South Africa and Ghana especially advanced [15,16]. Thus, in 2016, 43\% of Ghanaian adults were overweight or obese. Urban (48\%) populations were more obese than rural $(25 \%)$ and rates were higher among women (50\%) than men (28\%). Forty-three per cent of all adults in the Ashanti region were obese [17]. Similarly, in South Africa, $68.5 \%$ of women in urban areas were overweight or obese in 2015. The highest prevalence of female obesity (73\%) was recorded in the Western Cape province. The corresponding statistics for men are 34.2\% (SA urban) and 43.7\% (men, Western Cape) [18]. In Ghana, in $2011,23 \%$ of children were stunted nationally, and approximately $21.7 \%$ of children in the Ashanti region $[19,20]$. The 2014 Ghana Demographic and Health Survey reported that nationally $18.8 \%$ of children under five were stunted, while $16.1 \%$ in the Ashanti region. In South Africa, $26.5 \%$ of children under five were stunted in 2013 [21], and, in 2016, 27.4\% of children under five in South Africa and 22.9\% in the Western Cape were stunted [18]. Stunting in South Africa persists [22], with obesity often affecting other individuals in the same household [23].

High prevalence of obesity and stunting are linked to multiple dimensions of poverty and deprivation, including water, fuel, medicine, food and income [24]. De-agrarianisation is leading to increased urbanisation of poverty and food insecurity in Southern African [25-27] and West African cities [16,28]. Food insecurity contributes to nutrition transitions in low- and middle-income countries (LMICs), as food insecure households reduce dietary diversity and substitute cheaper foods such as starchy staples, sugar and oils. The level of national food insecurity in Ghana appears on the rise, especially in northern Ghana [29-31]. State estimates of food insecurity in Ghana suggest that about 5\% of the population are food insecure with another two million people vulnerable [30]. There seem to be few analyses of urban food insecurity for Ghanaian cities. Evidence from major cities such as Accra suggests that large percentages of the urban poor in Ghana experience food insecurity [32-34]. Accra households spend an average of $54 \%$ of income on food, meaning that they are vulnerable to food price fluctuations [34]. Kumasi has experienced significant poverty linked to challenges in governance and service provision, particularly the provision of water, sanitation, and markets critical for food provision [35]. Food insecure city dwellers in Ghana cope by reducing the amount of food consumed, consuming fewer portions, or substituting nutritionally inferior foods such as gari for rice [20] or cutting back on supplementary foods such as rice to enable consumption of primary staples such as maize or yam [36].

In middle-income but high inequality South Africa, food insecurity affects $54.3 \%$ of the population, with $28.3 \%$ at risk of hunger and $26.0 \%$ experiencing hunger. This is especially severe in urban informal 
areas (shantytowns), where $68.5 \%$ experience hunger or are at risk of hunger. In the Western Cape, $42 \%$ of households are food insecure [21]. Particularly high levels of urban food insecurity affect poor city-dwellers [37,38]. Levels of food insecurity in the low-income "black" African township of Khayelitsha are especially high, with $89 \%$ moderately or severely food insecure in a 2008 survey [39].

Both urban food insecurity and the nutrition transition are attributed to transformations of global food systems [40], understood as the web of processes, actors and infrastructure by which food is produced, processed, distributed and sold [41,42]. These transformations entail trade liberalisation, concentration in agrofood value chains, the dominance of corporate agribusiness, the rise of Big Food-large food manufacturing corporations which frequently operate at regional or global scales [43]. This has been accompanied by the expansion of supermarket retail and corporate fast food chains. Market liberalisation has facilitated food imports, enabling foreign direct investment into the expansion of formal retail and service outlets and supply chains, consolidation of value chains, and exposing domestic industry to increasing global competition. These dynamics accelerate the nutrition transition by making ultra-processed foods and animal protein products more available and affordable $[9,44-46]$.

\subsection{Obesogenic Food}

Several recent epidemiological studies and meta-analyses correlate dietary composition with obesity and NCD risk in the United States. These studies indicate that the consumption of ultraprocessed crisps, fried potatoes, sugar-sweetened beverages, processed meat, unprocessed red meats, sweets and desserts, butter or margarine, and refined grains (in descending order) are associated with increased risk of obesity and associated NCDs [47-50].

Consensus appears to be emerging on several key points. Firstly, there is increased emphasis on synergistic effects of nutrients, foods and patterns of food combinations, and reduced emphasis on individual nutrients of concern [51,52]. Secondly, total fat consumption itself is less problematic than long thought [51-54]. Instead, it is the type of fats which is critical: saturated fats derived from red meat and industrial trans-fats seem particularly risky, especially in combination with refined carbohydrates $[49,50,52,54]$. Deep-frying foods, especially starchy foods, tends to increase the trans-fat content of such foods making these particularly problematic in terms of obesity and cardiovascular health [51,52]. Neutral association was found for most dairy foods, except consumption of butter. Instead, thirdly, consumption of refined starches with a high glycaemic index (GI) and low fibre content, appear to be key factors promoting obesity and related NCDs [48,55,56]. Fourthly, and conversely, consumption of certain foods appears to reduce the risk of obesity and associated NCDs. These foods include whole grains, nuts, seeds, and fish high in polyunsaturated fats, as well as yoghurt, vegetables and fruit [51]. A fifth convergence entails the recognition that ultra-processed foods, cheaply mass-produced using multiple industrially-refined ingredients and additives, are consistently obesogenic and risky. These foods are being made increasingly available, accessible and desirable by Big Food corporations extending their reach into Africa $[43,57]$. The NOVA framework classifies food according to four types depending on the nature, purpose and extent of processing. Type one foods are whole and minimally-processed foods; Type two are ingredients such as oil, butter or sugar derived from whole foods; Type three are combinations of Types one and two, frequently used to preserve food; and Type four, ultra-processed foods, are typically industrial mass-products composed of multiple refined ingredients including sugar, cheap starches and oils, salt and various other additives which increase shelf life or alter the flavour, texture or colour of food. Examples include processed cheese, processed meats, confectionery, instant noodles, most breakfast cereals, and sugar-sweetened beverages. Consumption of ultra-processed food decreases intake of fibre, protein and various health-promoting micro-nutrients, while typically increasing the intake of free sugar, sodium and problematic fats. Detailed studies using this framework have been conducted in several countries. These 
studies have revealed a direct association between consumption of ultra-processed products and weight gain and increased risk for various NCDs [58-62]. The transformation of systems of food production towards industrial mass-production of ultra-processed food has been mirrored by other structural changes including the transformation of food retail.

\subsection{Changing Food Retail Environments}

Changes in retail, especially linked to the expansion of supermarkets in Africa, have transformed food environments. These changes have included centralised and consolidated procurement and distribution systems of increasingly regional scale, more direct contractual relationships with large-scale producers and suppliers who are able to meet demanding formal-sector standards. These upstream trends are matched by a downstream diffusion and penetration of "supermarkets for the poor" into areas previously dominated by traditional and informal markets $[46,63]$.

Ultra-processed foods are becoming increasingly dominant in the global food system [64]. In Ghana, not only has there been a rise in supermarkets but ultra-processed foods have also penetrated the traditional food retail outlets and are widely available. Although about $6 \%$ of processed foods in Ghana are imported from South Africa, they derive predominantly from continents other than Africa [65]. In South Africa, the food retail transition has unfolded extensively-shopping malls and supermarkets are rapidly expanding into erstwhile underserviced, impoverished neighbourhoods, as documented for Cape Town [66-69]. This expansion and the entry of more vertically-integrated networks of informal shops which employ more competitive business practices appears to be transforming the local informal economy [70]. This represents a hybrid system with a highly consolidated formal core and an informal periphery closely linked to the formal economy and to transnational networks of people, goods and finance $[5,67,68]$.

However, these transformations in economic regimes and food systems take place at a scale which is far removed from the everyday lived experience of the many poor who are affected. Paradigmatic food systems models emphasise the global and national scale [41,42,71], or discuss household food security outcomes while neglecting intermediate scales of analysis [4]. Consequently, there is a theoretical disjuncture between macro-scale transitions and shifts in household purchasing and consumption patterns. Structural determinism emphasising systemic transitions fails to show how food system change translates into micro-level dietary changes and neglects how the the poor respond to structural change and how these responses in turn might influence systemic transitions. Finally, while trade and investment policy could influence food environments at a national scale by limiting the import and raising costs of problematic foods, global and regional processes are beyond the reach and remit of local governance. This raises the question how local governance processes can engage with these macro-level drivers of food systems transitions.

\subsection{Food Environments in South Africa and Ghana}

The concept of food environments introduces an intermediate scale of analysis which may bridge this gap [72-74]. Conceptually, food environments enable, constrain and shape people's food purchase and consumption patterns in several ways related to food availability, accessibility and affordability, and desirability. The notion of food environments still suggests an environmental determinism wherein external environmental factors decisively shape people's purchasing and consumption behaviour. However, this should not lead to neglect of the specific role played by poverty and its various implications. For this reason, we also draw attention to systemic disadvantage faced by poor people. The poor inhabit food geographies differently from wealthier populations, and analysis needs to be sensitive to that and to how large-scale poverty itself shapes the nature of markets. In this sense, the nature of the retail environment 
and the strategic decisions of food retailers themselves are shaped by the constraints on aggregate demand in poor food geographies.

A multi-scale perspective on food environments suggests distinctions between personal and external food environments composed of various factors emanating from different scales, e.g., local, national, regional, and global [73]. For this paper, we do not consider the personal scale, but two intermediate scales instead: the household and neighbourhood (i.e., within walking distance of a household) food environment, and the degree to which broader structural drivers such as poverty and food systems transitions influence these. This perspective reveals how systemic transformations change the nature of the local environments which shape the availability and accessibility of food. Conversely, household food purchasing and consumption patterns aggregate to reinforce structural shifts, suggesting multiple cross-scale feedback loops. The food environment concept also has implications for food governance because it frames food consumption drivers at a territorial scale that is amenable to local policy, planning and design interventions $[75,76]$ while also making explicit linkages to higher levels of scale such as regional and global flows of goods and finance.

Food environments in Ghana and South Africa are characterised by a mix of formal and informal food outlets. Informality entails various economic activities which operate without formal registration for tax, licensing, or providing employee benefits such as retirement or paid leave [77]. The informal sector is a key source of food for the poor $[39,78,79]$ but this role is not adequately considered in policy debates [80] and is still poorly researched [81]. Supermarkets and the informal food economy provide different and complementary retail sources of food $[66,68,82]$. Informal food trade presents advantages to the urban poor: affordable unit sizes, convenient locations, long opening hours, credit, daily re-stocking of fresh produce, which is often cheaper than at supermarkets, and meat cuts that cater to cultural preferences. However, there are disadvantages, too, such as higher unit costs for non-perishables, a limited range of goods of perceived lower quality and shorter shelf life due to the lack of a cold chain, and perceived food safety risks particularly in meat retail. The informal economy thus offers food sources which respond to key needs of poor consumers. This is particularly relevant in cities where unemployment and poverty are often concentrated in fragmented and remote peri-urban informal settlements [83,84].

Food environments in Ghana have traditionally been characterised by large markets and ubiquitous informal roadside stalls and shops. Although research on urban food environments in Ghana is limited, it appears that they are undergoing considerable changes, with increasing prevalence of supermarkets commonly frequented by wealthier city-dwellers, while open-air markets and hawkers are more usually patronised by the poor [85,86]. Fruit and vegetables are scarce in some areas [33], while there is an abundance of cooked foods and convenience stores selling processed and ultra-processed foods that require little or no cooking before consumption. In Accra, informally-sourced food comprised mainly polished rice, vegetable oil, frozen chicken and frozen fish. Increased density of convenience stores appears associated with increases in BMI [87], but food safety issues seem of primary policy concern in Ghanaian and South African cities. Research has therefore emphasised the risks of microbial contamination $[34,88,89]$ and pesticide residues $[81,90]$ in the informal economy.

In South Africa, consumption of street foods correlates with low dietary diversity. Despite widespread consumption of fruit from street trade, there is also a high consumption of ultra-processed foods such as sugar-sweetened beverages and savoury snacks [91]. In poorer areas of Cape Town, food environments promote unhealthy choices [92]. In addition to a challenging food environment, a lack of public safety discourages physical activity, converging with psychosocial stress to promote NCDs, particularly in settlements such as Khayelitsha $[93,94]$. 


\subsection{Framing Food Environments as Objects of Governance}

Key elements of African food systems are clustered in cities, including retail, distribution and processing, presenting opportunities for improved governance [95]. Given the importance of food environments, it is clear that they warrant more effective governance. Governance typically involves various combinations of hierarchical state power, indirect governance through markets, and "adaptive governance" through transversal multi-stakeholder networks and alliances [94,96]. A growing food systems governance narrative emphasises adaptive governance eliciting multi-stakeholder participation [97-100]. There is a growing movement in cities of the Global North towards the democratisation of food systems governance at the urban scale through mechanisms such as departments of food, food policy councils, local food charters, and extensive processes of public participation [4]. Proponents also advocate the incorporation of food issues within urban planning, design and management, for example through food sensitive planning guides or incorporation within local ordinances [101]. However, this requires the development of suitable indices, measurement technologies, and data collection to set benchmarks, design interventions and assess change [102,103]. For governance purposes, complex data need to be simplified and aggregated to render them accessible and amenable to interpretation and intervention by non-academics such as officials, activists and designers. Charts and maps [104] are among the media used to promote discursive and policy aims in ideologically loaded and contested environments [104-106]. These media can draw on novel sources of data by leveraging technical innovations that facilitate the rapid and simple collection of geo-referenced data. These approaches permit the spatial representation of food-related datasets, thus making them more relevant for spatial planning and urban design, which are key local governance competences. However, such media can be obscure and exclusionary. This paper therefore builds on previous approaches [82,107] to develop ways to make the hybrid and diverse food environments of African cities visible, accessible and legible.

\subsection{Research Question}

This paper explores correlations and linkages between neighbourhood food environments and household food environments, with particular emphasis on the risk they pose for obesity. At the household scale, we are concerned with household purchasing and consumption patterns as elements of household food environments, rather than as a reflection of individual consumption. We are thus interested to know household consumption levels of obesogenic foods and diverse healthier foods, and the aggregate patterns of consumption. At the neighbourhood level, we are interested to describe the density of food outlets, their variety, and the types of food available. The underlying interest is to understand to what extent food outlets in the local food geography facilitate the consumption of obesogenic foods or of healthier food options. The second line of inquiry considers the policy, planning and governance implications of these findings.

\section{Materials and Methods}

The study gathered quantitative data linking household consumption patterns and local food geographies. Two analytical approaches are combined in this paper. Firstly, descriptive statistics are employed to reflect key features of household and neighbourhood food environments in the research sites. This includes the number and density of food outlets and the relative availability of obesogenic foods in diverse food outlets. Secondly, geo-referenced indices of provision and consumption of obesogenic food are mapped to reveal potential spatial correlations between food consumption and food environments. Ethics clearance was obtained in South Africa from the University of the Western Cape research ethics council (BM17/8/20) and in Ghana from the Centre for Scientific and Industrial Research (CSI: RPN 011/CSIR-IRB/2017). 


\subsection{Sites, Instruments and Analysis}

Two urban research areas in Ghana and South Africa, namely Khayelitsha (Cape Town) and Ahodwo (Kumasi), were chosen. Khayelitsha was chosen as an urban South African site due to previous research experience in the neighbourhood, its large population of urban poor, and its peripheral geographic location. It is located on the far outskirts of the Cape Town metropolis, a major port city with 3.4 million inhabitants. Ahodwo is a central suburb of Kumasi, a metropolis of approximately two million people located in the central Ashanti region of Ghana. Kumasi was chosen as an urban area due to the high level of development and socio-economic status of residents. The spatial dislocation of Khayelitsha as a remote peri-urban dormitory settlement, a legacy of apartheid-era spatial planning, reinforces poverty as it traps the urban poor in areas far from job opportunities $[83,84,108]$. By comparison, Ahodwo is located fairly centrally in the Southeast of Kumasi metropolis, which reflects a ubiquitous and vibrant street economy.

Digital survey instruments utilising the ODK smartphone survey app were developed in a consultative process involving the entire interdisciplinary research team. The instrument incorporated standardised survey instruments such as the Lived Poverty Index [24] as well as the adapted PURE food frequency questionnaire incorporating the NOVA classification framework. Surveys were additionally reviewed and validated by enumerators as part of an iterative training process including several workshops to ensure clarity and consistency of comprehension. A link to the survey instruments is in the appendix. The instrument was pilot-tested with a small sub-sample of respondents to further assess comprehension and time required. The survey recorded: (i) key aspects of household socioeconomic status and foodways including consumption, sourcing, and preferences; and (ii) the types of outlet, the variety of food sold, key aspects of business practice such as operating times, upstream sources, and modes of provisioning. Georeferences were recorded for each survey response. The research teams in Ahodwo selected a six-area sample frame demarcated by a roundabout and two exit roads which border the township (Figure 1). Two survey areas were selected in Khayelitsha using a transect principle (Figure 2). The one area is Site B, the other is Enkanini-Makhaza. The transects focused on a central zone defined by the railway stations, adjacent minibus taxi ranks and nearby shopping mall complexes. Data were gathered between September and November 2017. Enumerators walked along the roads identified in the sample frame and selected residential properties in the Khayelitsha sampling frame on a 1 in 7 ratio, and in Ahodwo on a 1 in 5 ratio. Enumerators interviewed the household member most knowledgeable about food purchasing and consumption. Enumerators sought to interview all food outlets within the sample frame. Because the sampling rate in Khayelitsha was higher and properties smaller, the sample frame area in Khayelitsha was also smaller (1.32 $\mathrm{km}^{2}$ as compared with $\left.5.62 \mathrm{~km}^{2}\right)$. 


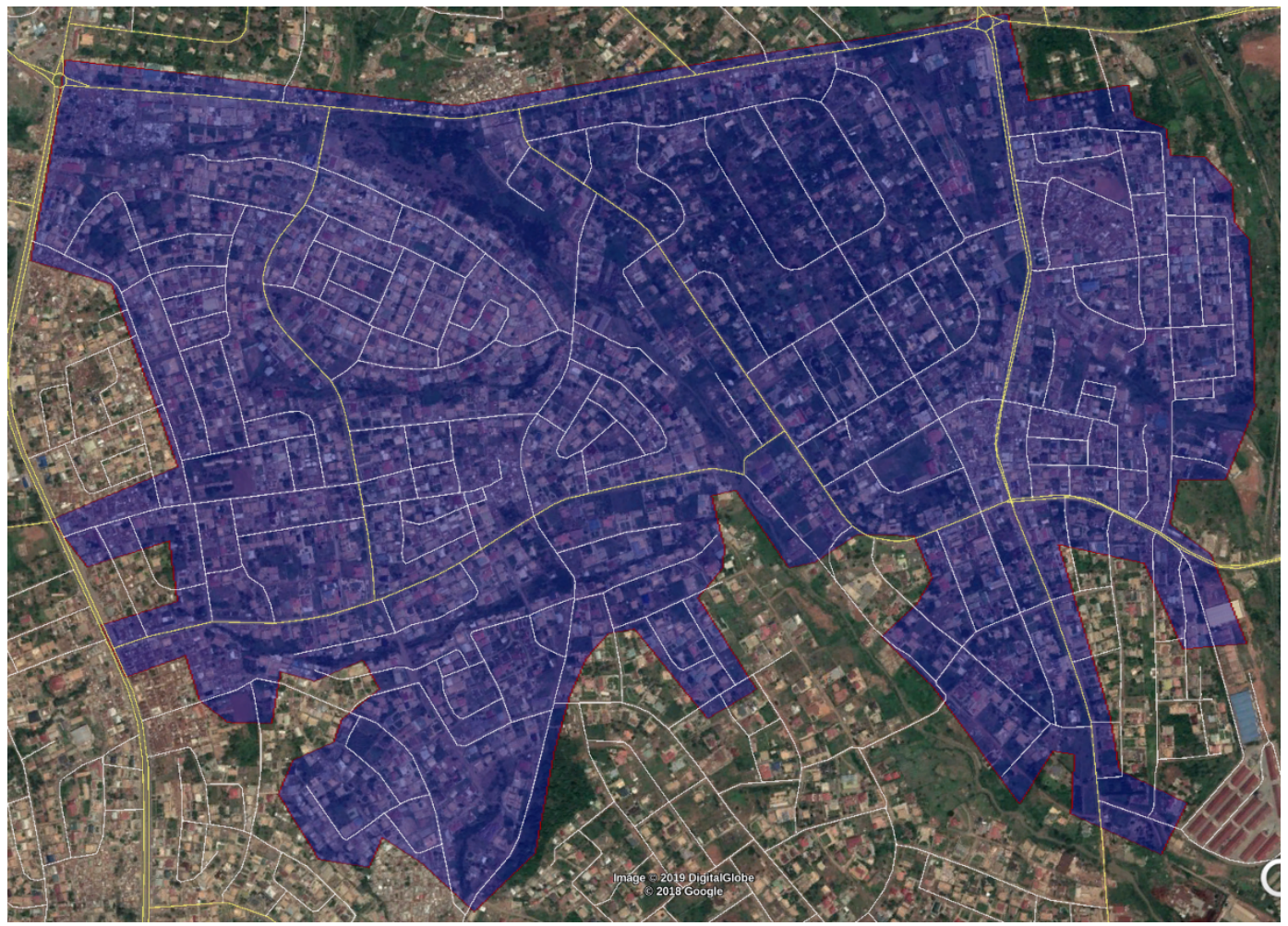

Figure 1. Ahodwo Sample Frame, $5.62 \mathrm{~km}^{2}$.

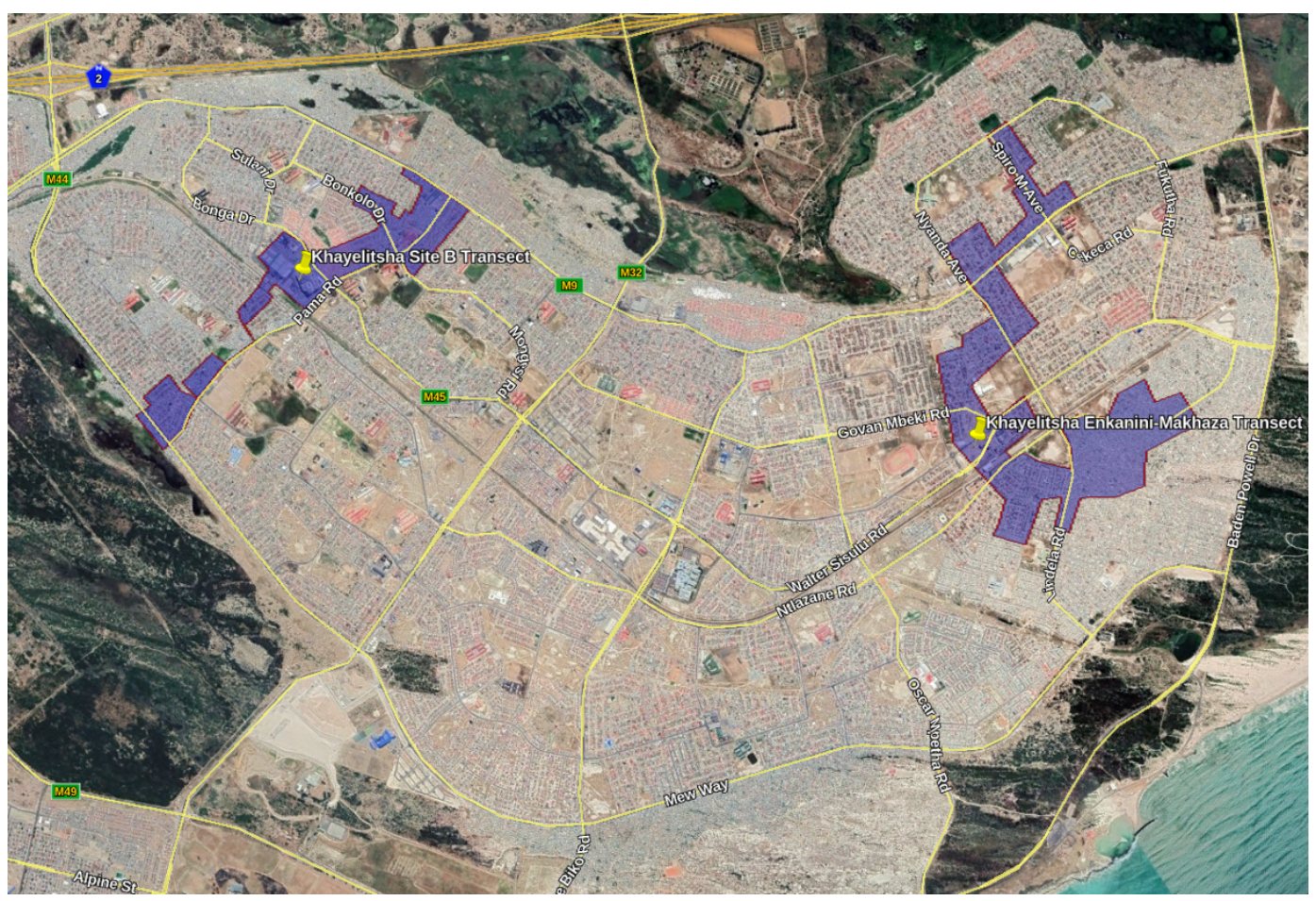

Figure 2. Site B (far left) and Makhaza-Enkanini (far right) sample frames $1.32 \mathrm{~km}^{2}$. 


\subsection{Analysis}

Data were anonymised and cleaned by checking for inconsistencies, identifying outliers, and correcting obvious errors contradicting known observations (especially for fast food outlets). In some cases, georeferences could not be collected due to technical errors or because enumerators considered the use of smartphones unsafe. In these cases, georeferences were randomly allocated based on the approximate location of the sample.

Customised analysis frameworks for both household and neighbourhood scales were developed on google sheets. Standard spreadsheet functions were used to recode data to generate composite indices of obesogenic and protective food provision and consumption. These were analysed using descriptive statistics such as counts and frequency distributions. Crosstabulations were done to compare dietary risk class distribution between Ahodwo and Khayelitsha samples, internally between income-deprived and non-deprived households in each area sample, and between outlet risk distribution in both sites. Significance of distribution patterns were tested using Pearson's chi-square test. Finally, the correlation (r) between provision and consumption risk classes was tested for both sites.

\subsection{Food Outlet Typology}

Food retail and service providers were categorised according to a typology based on whether the outlet was located in public or private space, their trading history or temporal persistence and the degree to which permanent or fixed structures have been built. This typology draws on previous work done by AFSUN [37,82]. The food provider typology included the food retail and service categories shown in Table 1.

Table 1. Food outlet typology.

\begin{tabular}{cl}
\hline \multicolumn{1}{c}{ Outlet Type } & Outlet Detail \\
\hline Formal retailer & Wholesaler/Distributor; Supermarket; General dealer \\
\hline Small or informal shop & $\begin{array}{l}\text { Small shop/Convenience store/Spaza (dedicated shop with a sign); House-shop } \\
\text { (informal shop attached to or part of a home; no sign; not dedicated to food retail only); } \\
\text { Container shop }\end{array}$ \\
\hline Stall or mobile trader & $\begin{array}{l}\text { Fixed municipal stall (with shelter and display); Permanent stall (fixed shelter, table } \\
\text { and display shelves which stays in place after trading hours); Temporary stall (boxes } \\
\text { with board; removable stall and shelter; trailer with wheels); Mobile trader (trolley, } \\
\text { wheelbarrow; carry-tray, basket or buckets); Bakkie (pick-up truck) trader or trike. }\end{array}$ \\
\hline Formal food service & Formal restaurant; Corporate fast food shop; Independent take-away/fast-food. \\
\hline Informal food service & Informal restaurant; Informal take-away or grill. \\
\hline
\end{tabular}

It is important to note that there are significant differences between South African and Ghanaian supermarkets. In South Africa, this usually means a large floor space (200 $\mathrm{m}^{2}$ or more), multiple aisles, trolleys, large-scale refrigeration, multiple ( 5 or more) electronic tills with card payment facilities, barcode scanning systems used for electronic inventory management, and typically also corporate ownership or formal franchise operations with standardised corporate image and branding. By contrast, in Ghana, supermarkets are often smaller operations with floor space of $100 \mathrm{msq}$ or greater. Where the supermarket is owned by a multinational company such as Shoprite, its characteristics are similar to that described for South Africa. Supermarkets may have some features such as trolleys, multiple aisles, barcode scanning systems, etc., but on smaller scales. Additionally, cash is the typically accepted mode of payment in most Ghanaian supermarkets. 


\subsection{Obesogenic Food Consumption and Provision Indices}

To operationalise the concept of obesogenic food environments, a nutritional classification framework was developed for the household and neighbourhood scales of analysis. This interpretive framework was informed primarily by relevant literature and deliberation among the authors. Although it requires further validation [109-111], in the absence of suitable alternatives, it represents a transparent and evidence-based framework which renders a high degree of complexity visible and legible. Food groups were allocated to two classes of obesity risk-risky and protective-based on their composition and their classification in terms of the NOVA system. The household questionnaire recorded the frequency of consumption of various foods but not the quantity. Consequently, this framework considers both frequency and diversity, but cannot predict dietary adequacy without further validation. Table 2 reflects the different foods considered part of the obesogenic risk index. Only foods where the evidence for impacts on obesity was clear and compelling were considered. Other foods, where the evidence is more ambiguous (e.g., maize meal, red meat, and chicken), were not counted towards the obesity risk index. Both white and brown bread in both sites were classified as ultra-processed food due to the typically high-volume, industrial Chorleywood production process involved [112], which results in just slightly more fibre in the brown bread, although otherwise almost identical with white bread. Nuts and seeds were not included as review of brand information showed that these typically had high salt and added oil content, which arguably offset possible nutritional benefits. A frequency cut-off was set to establish whether a given food is consumed frequently enough to contribute to obesity risk or prevention. Two or more occasions of consumption per week was selected as reflecting frequent consumption for risky foods, five per week for protective foods, as these need to be consumed at a high frequency in order to provide protective benefit. The obesogenic cutoff is set low in order to ensure the index is sensitive to the aggregate effects of occasional consumption of different obesogenic foods. A second cutoff was set to test for the number of foods exceeding the first (frequency) cutoff. As there is a larger number of food types in the risky category than in the protective category, this class has a higher cutoff (4) for number of foods. For example, if a household reported consuming processed meat three times a week, industrial bread five times a week, cookies twice, and sugar-sweetened beverages every day, they would have reached the cutoff for intake of obesogenic foods. If they also ate fruit only once or twice a week, cooked vegetables and legumes five times a week, and no other protective foods, the diet would not reach the minimum cutoff to be classed protective. A binary index was computed based on the number of foods that exceeded frequency cutoffs in either of these categories. This was used to compute a two-category "risk index" and a "protective index". Above the cutoff, that category was scored with 1 , where it was below the limit, the category score is 0 (Table 2).

Table 2. Food consumption risk classes.

\begin{tabular}{|c|c|c|}
\hline Household Consumption Risk Class & Risky & Protective \\
\hline Description & $\begin{array}{l}\text { Ultra-processed, processed and } \\
\text { fried foods and ingredients }\end{array}$ & $\begin{array}{l}\text { Minimally-processed, } \\
\text { plant-based foods }\end{array}$ \\
\hline Cutoff frequency & $2-4$ times a week or more & 5 times a week or more \\
\hline Cutoff number of foods & 4 & 3 \\
\hline Food types & $\begin{array}{l}\text { Processed Meat; Instant Noodles; } \\
\text { Salty snacks; Sugary drinks; } \\
\text { Ready-to-eat foods; Fast food; Fried } \\
\text { potatoes/hot chips; Processed } \\
\text { Dairy; Breakfast cereals; Sweets; } \\
\text { Confectionery; Sugar; } \\
\text { Vetkoek/Dumpling; Commercial } \\
\text { Bread-White; Commercial } \\
\text { Bread-brown }\end{array}$ & $\begin{array}{l}\text { Vegetables—fresh; } \\
\text { Vegetables-cooked; Vegetables } \\
\text { (fried/stir fry); Fruit; Legumes; } \\
\text { Bread-wholewheat; Fish }\end{array}$ \\
\hline
\end{tabular}


The same logic was followed to develop a synoptic indicator of the degree to which food outlets provide access to foods promoting obesity. A list of food types traded was assessed in terms of the obesity risk these foods pose. A threshold of two foods traded was set for each category. An outlet was scored high-risk if the outlet stocked two or more risky food types, low-risk if it stocked only one or less. Similarly, an outlet was scored based on the provision of foods known to mitigate obesity risk (Table 3). Low risk foods include mainly NOVA Class one (whole) staples such as maize meal, rice, potatoes, meat, eggs or Class two (refined ingredients such as oil). Where details of shop stock were not available due to refusal to participate in the survey, a score was interpolated based on average scoring of similar outlets and description of type of outlet (e.g., unsurveyed "fruit and veg stalls" were scored as "low risk and protective" as this was the dominant scoring for similar stalls).

Combinations of these two binary indices were used to calculate an aggregate risk index based on four mutually-exclusive categories of obesity risk and vulnerability of household and neighbourhood food environments (Table 4 below).

Table 3. Food provision risk classes.

\begin{tabular}{|c|c|c|}
\hline Class & Risky & Protective \\
\hline Description & $\begin{array}{l}\text { Ultraprocessed and obesogenic foods high in salt, sugar } \\
\text { and saturated fats }\end{array}$ & Minimally processed, nutrient-dense foods \\
\hline Threshold & 2 & 2 \\
\hline Foods & $\begin{array}{l}\text { Instant Noodles; Confectionery and Sweet Snacks; Sweets; } \\
\text { Sugar-sweetened beverages; Salty Snacks; Dairy, } \\
\text { Ultraprocessed; Meat, Ultraprocessed; Commercial bread; } \\
\text { Breakfast Cereals; Flour-based meal with roasted or baked } \\
\text { additions, (e.g., burger, pizza, dagwood, gatsby, kota); } \\
\text { Dessert; Confectionery (Cookies, scones, muffins); Sugar; } \\
\text { Deep fried starchy food (deep-fried dumpling, potato chips) }\end{array}$ & $\begin{array}{l}\text { Fruit; Vegetables; Legumes; Legumes, cooked; } \\
\text { Vegetables, cooked or fried; vegetables and } \\
\text { relish; Fish, cooked or grilled; Fish }\end{array}$ \\
\hline
\end{tabular}

Table 4. Food environment risk and vulnerability matrix.

\begin{tabular}{cll}
\hline Household & PI 1 & PI 0 \\
\hline RI 1 & $\begin{array}{l}\text { high risk, protective (households frequently } \\
\text { consume risky foods but also protective foods) }\end{array}$ & $\begin{array}{l}\text { high risk, vulnerable (households } \\
\text { frequently consume risky foods, } \\
\text { but lacking adequate protective } \\
\text { food consumption) }\end{array}$ \\
\hline RI 0 & $\begin{array}{l}\text { low risk, protective (households consume } \\
\text { risky foods infrequently, and frequently } \\
\text { consume protective foods) }\end{array}$ & $\begin{array}{l}\text { low risk, vulnerable (households } \\
\text { infrequently consume risky foods } \\
\text { but also consume inadequate } \\
\text { protective foods) }\end{array}$ \\
\hline Neighbourhood & $\begin{array}{l}\text { High risk and protective (outlet stocks a wide } \\
\text { variety of high risk and protective foods) }\end{array}$ & $\begin{array}{l}\text { High risk (outlet stocks a variety of } \\
\text { high risk foods but few protective) }\end{array}$ \\
\hline RI 0 & $\begin{array}{l}\text { Low risk and protective (outlet stocks a } \\
\text { variety of low-risk and protective foods) }\end{array}$ & $\begin{array}{l}\text { Low risk (outlet stocks mainly } \\
\text { low-risk staple foods and few } \\
\text { protective or high-risk foods) }\end{array}$ \\
\hline
\end{tabular}

In the household example just mentioned, the household would be considered high-risk and vulnerable. Outlets marked as low-risk would stock few ultra-processed food types, but mostly the low-risk, minimally-processed foods mentioned above. Outlets stocking a variety of foods known to protect against obesity were classed as protective. Thus, supermarkets would generally be scored as "high risk and protective" as they provide access to both types of foods, while fruit and vegetable stalls 
would generally be scored as "low risk and protective" because they do not stock a variety of obesogenic foods but offer various protective foods. The statistical distribution of households and food outlets belonging to these different risk classes was calculated at both the household and neighbourhood level. At the neighbourhood level, this distribution was calculated with reference to the number of food outlets per square kilometre. Household and neighbourhood food environment categories were mapped.

\section{Results}

In Khayelitsha, 327 households participated in the survey and 309 households in Ahodwo. Response rates were $91 \%$ and $97 \%$, respectively. In total, 407 outlets were surveyed in Ahodwo and 83 in Khayelitsha. However, the outlet response rate in Khayelitsha was low (53\%), possibly due to mistrust related to recent xenophobic persecution of foreign-owned informal outlets in South Africa [113] and absence of shop-owners. By contrast, $100 \%$ of Ahodwo retailers agreed to participate in the study. Descriptive statistics and maps reflecting survey findings are presented in the following two sections. The first section presents the distribution of the aggregate household risk index and profiles the key obesogenic and protective foods consumed. The second section first presents the diversity of food outlets in the local food environment, then maps the aggregate food provision index, juxtaposing this with aggregate food consumption.

\subsection{Household Food Environment}

The findings reflected in Figure 3 show that $71 \%$ of Khayelitsha respondents reported household diets that met or exceeded the cutoffs for obesogenic foods, while only $16 \%$ reported consuming diets meeting or exceeding cutoffs for protective food. In Ahodwo, the pattern is different, with approximately one quarter of households surveyed (26\%) consuming diets high in obesogenic foods, and only $23 \%$ consuming high amounts and varieties of protective food. Here, two thirds of respondent households consumed low-risk diets composed largely of minimally-processed staples but lacking in protective food intakes. In both samples, there is a notable dearth of protective food consumption. The difference in the risk class distribution between the two sites is statistically highly significant $(p<0.000)$.
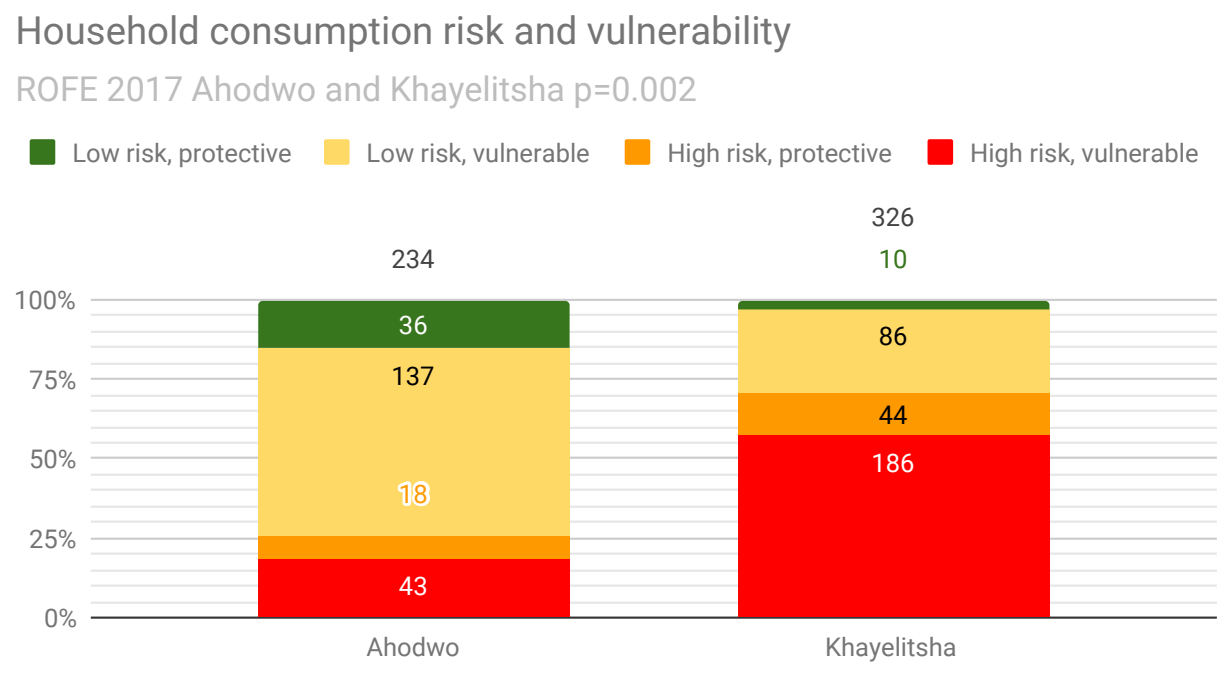

Research site

Figure 3. Household consumption risk and vulnerability classes—numbers on the bars reflect class and aggregate totals. 
Figure 4 shows which of the high-risk foods most commonly exceeded the thresholds. In Khayelitsha, commercial bread, sugary drinks, processed meat and sugar were the most prevalent obesogenic foods. In Ahodwo, commercial bread was followed by sugar, sugar-sweetened beverages, and confectionery as the top four high-risk foods exceeding threshold.

In Khayelitsha, the top three protective foods consumed were fruit, fresh and cooked vegetables (Figure 5). More than a third of households met the threshold for "protective" fruit consumption, just more than a third for cooked vegetables but just more than one in ten met the threshold for fresh vegetables. In Ahodwo, fish and fruit (38\% each) were the most common obesity-mitigating food consumed at or above threshold, followed closely by cooked vegetables (28\%). Only about one in five households (23\%) exceeded the frequency threshold for fresh vegetables.

In Khayelitsha, supermarkets and formal retail outlets clearly dominate as sources for most foods except fruit, bread and sugary drinks (Figure 6). Informal and small shops dominate as sources of bread and sugary drinks, but play a minor role in the provision of protective food options. Informal stalls play an important role in the provision of fresh fruit and vegetables.

In Ahodwo, small shops play a greater role in providing access to the key foods than in Khayelitsha (Figure 7). Formal retailers are also a key source of sugary drinks, confectionery and sugar. Fruit, vegetables, legumes and fish are provided primarily by stalls and by "other", which mostly refers to open markets, table top (stationary) food vendors as well as mobile food vendors.

\section{Consumption of high obesity risk foods above threshold}

\section{ROFE 2017 Ahodwo and Khayelisha}

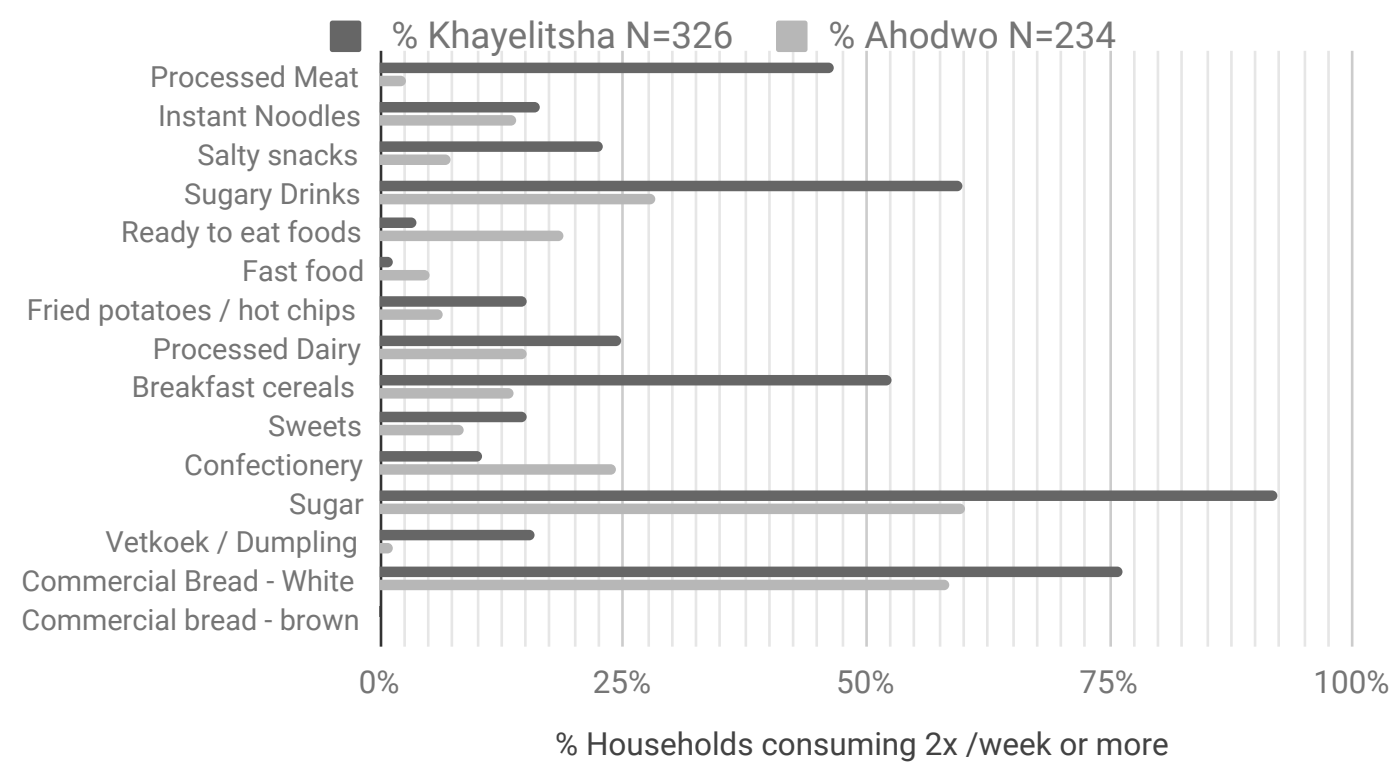

Figure 4. High-risk household food consumption above threshold. 


\title{
Household consumption of health-promoting foods above threshold
}

\section{ROFE 2017 - Ahodwo and Khayelitsha}

\author{
$\%$ Khayelitsha $\mathrm{N}=326$ \\ $\%$ Ahodwo N=234
}

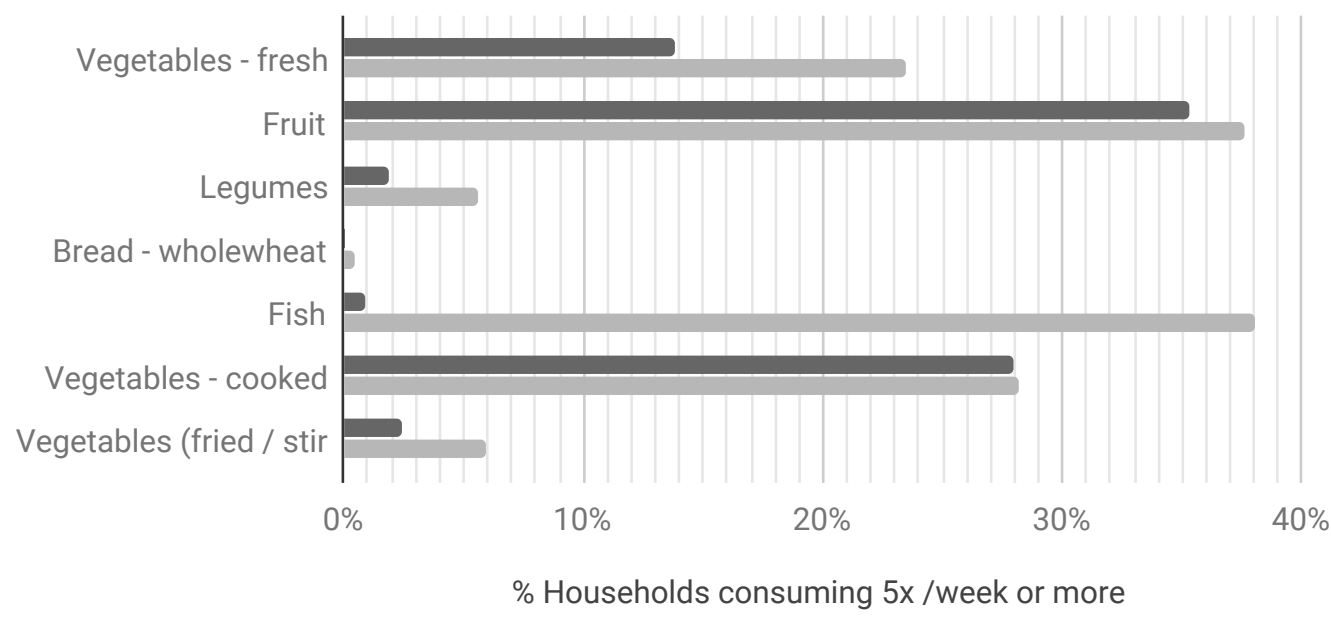

Figure 5. Household consumption of protective foods above threshold.

\section{Key Food Sources - Khayelitsha}

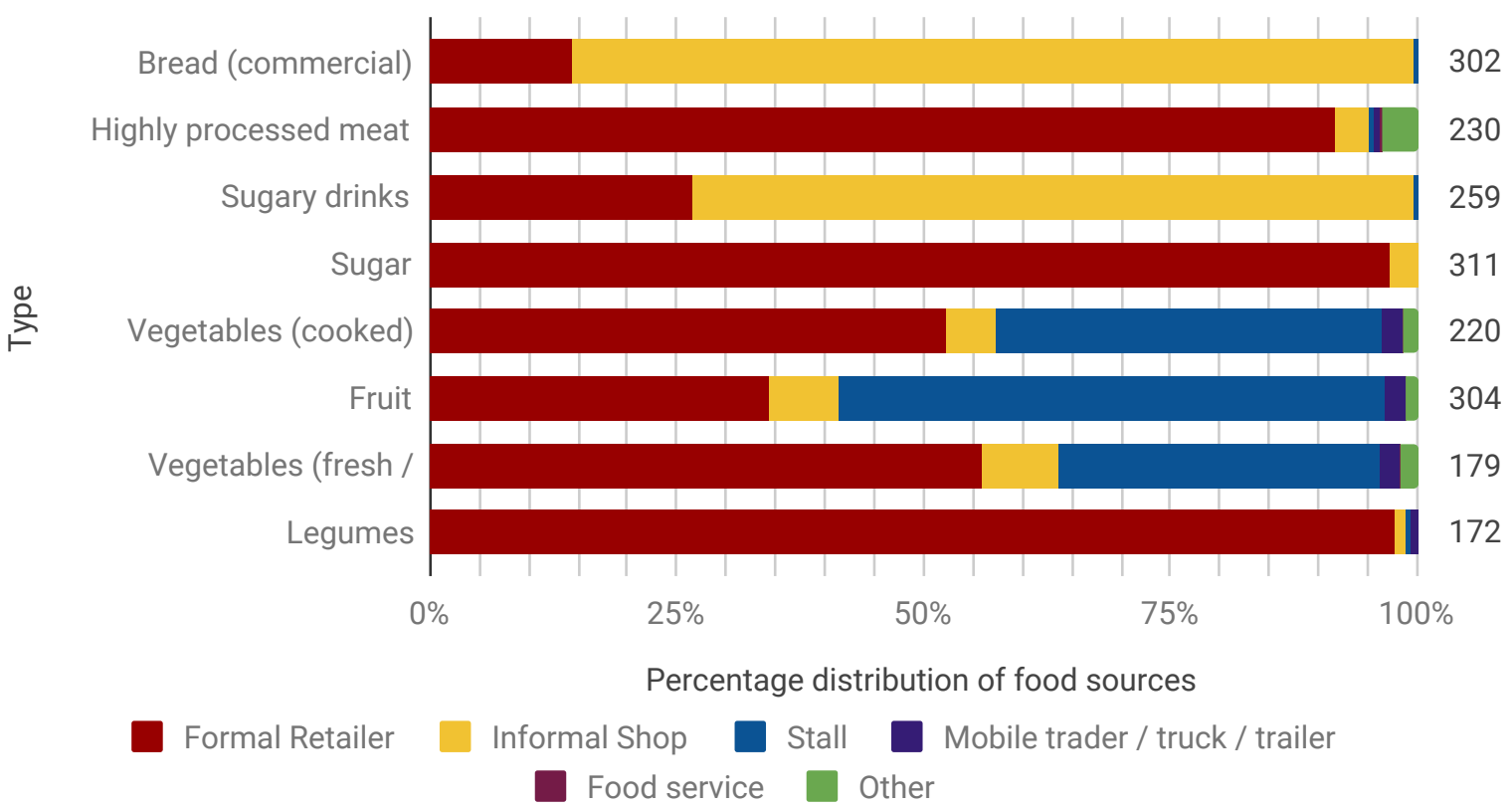

Figure 6. Household sources of key foods in Khayelitsha-numbers on the right reflect total counts of households consuming each food. 


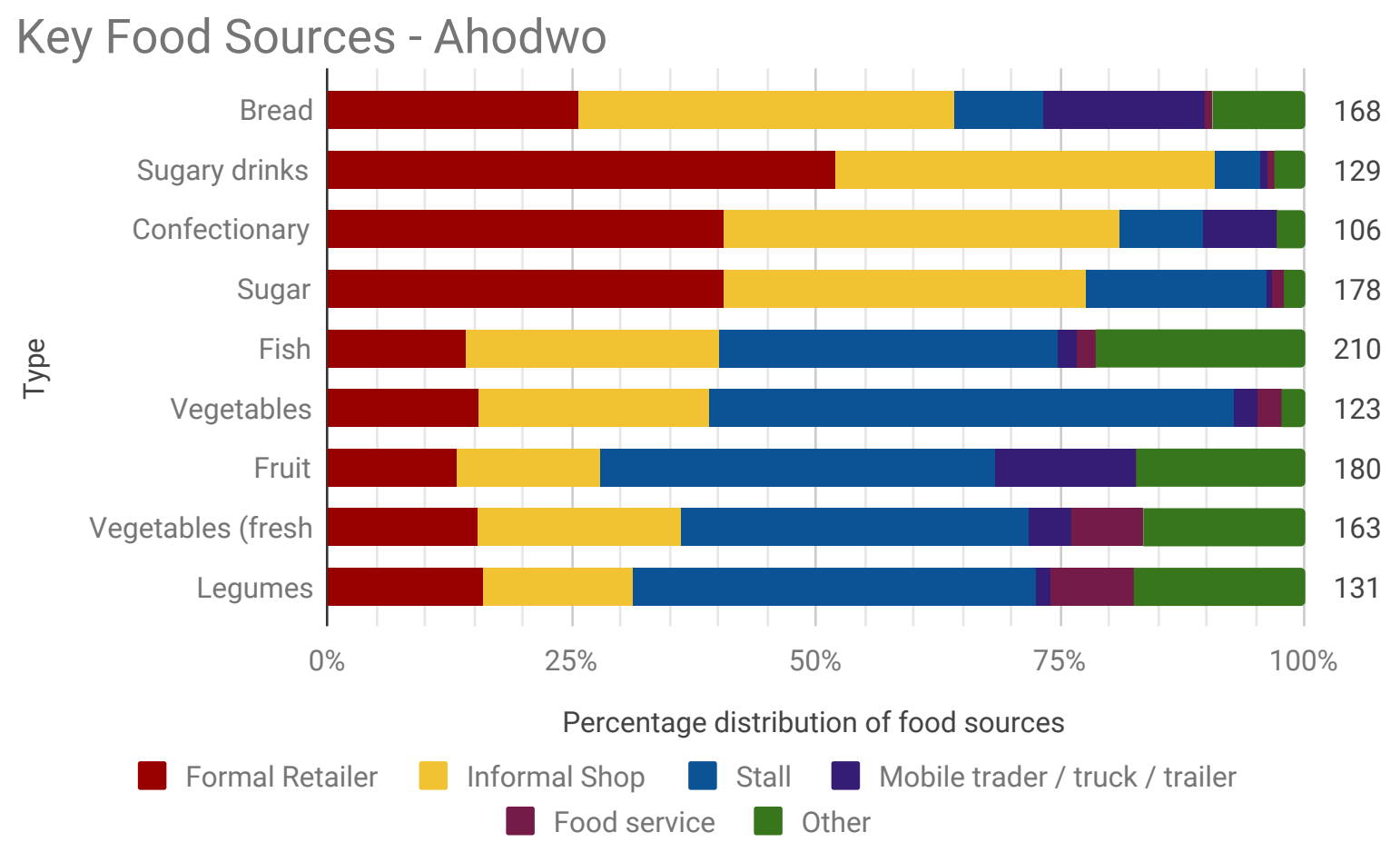

Figure 7. Household sources of key foods in Ahodwo-numbers on the right reflect total counts of households consuming each food.

\subsection{Neighbourhood Food Environment}

The Ahodwo sample frame contained a far larger number of both food retail and food service outlets than the Khayelitsha sample frame due to the larger geographical area (Table 5). However, food retail outlets are represented at similar densities of approximately $39 / \mathrm{km}^{2}$ in Khayelitsha and $41 / \mathrm{km}^{2}$ in Ahodwo. Food service outlets are represented slightly more densely in Ahodwo, with $32 / \mathrm{km}^{2}$ as opposed to $23 / \mathrm{km}^{2}$ in Khayelitsha. The proportions of the different outlet classes are similar in both sites. Ahodwo has more outlets per square kilometre, but in Khayelitsha the proportions of outlets providing access to obesogenic as well as those providing protective food are larger (Figure 8). The difference in distribution between the two sites is statistically significant at $p=0.0001$. This indicates that Khayelitsha residents have fewer outlets to choose from, and that, of those, more than half (57\%) are risky, as opposed to one in three in Ahodwo (39\%). However, Ahodwo residents appear to have poorer aggregate access to protective foods (16\% vs. $43 \%)$.

Table 5. Number and composition of food outlets.

\begin{tabular}{ccccc}
\hline Outlet Type & Ahodwo & Khayelitsha & \% Ahodwo & \% Khayelitsha \\
\hline Formal Retailer & 27 & 6 & $7 \%$ & $7 \%$ \\
Informal Shop & 109 & 27 & $27 \%$ & $33 \%$ \\
Stall or mobile trader & 89 & 19 & $22 \% \& 23 \%$ & \\
Formal food service & 58 & 12 & $15 \%$ & $14 \%$ \\
Informal food service & 116 & 19 & $29 \%$ & $23 \%$ \\
\hline
\end{tabular}




\section{Food outlets per square kilometre by obesity risk}

\section{ROFE 2017 - Ahodwo and Khayelitsha $p=0.0001$ \\ Low risk and protective $\square$ Low risk $\square$ High risk and protective $\square$ High risk}

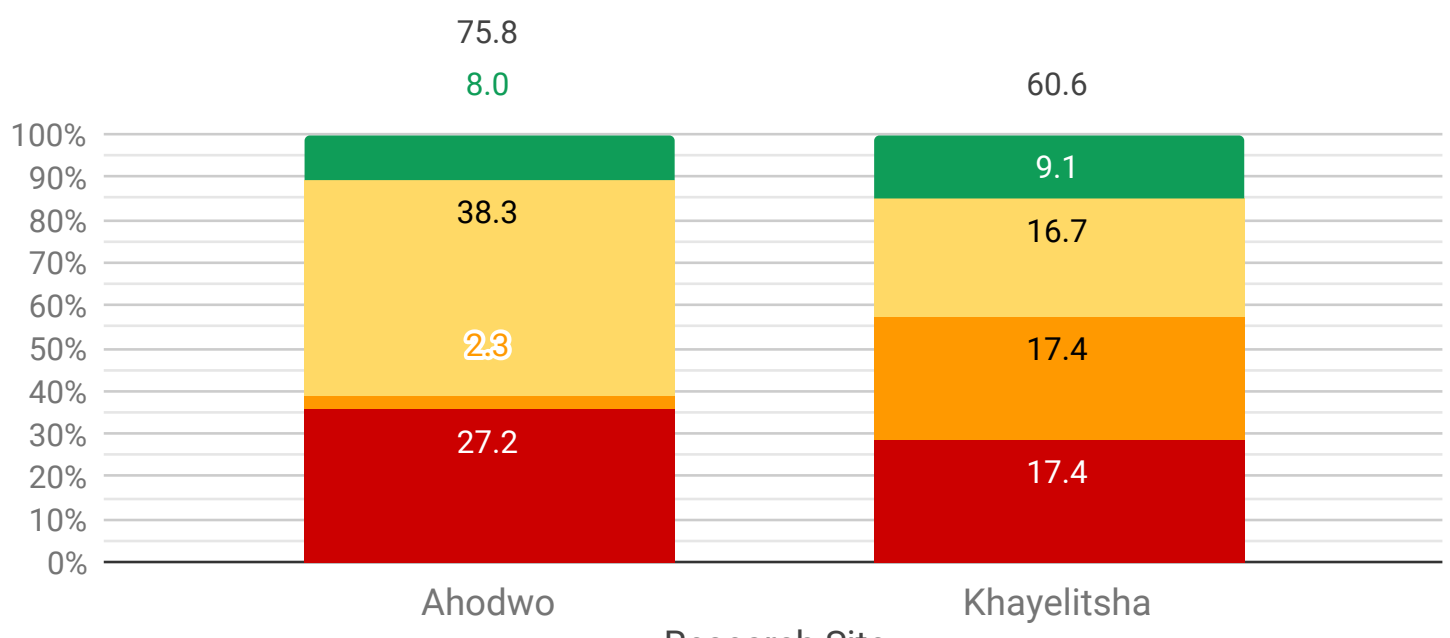

Research Site

Figure 8. Food outlets per square kilometre by risk and protection class-numbers reflect class and aggregate totals.

The distribution of household and neighbourhood food environment classes show a strong $(\mathrm{r}=0.862)$ positive correlation in Ahodwo, while the correlation in Khayelitsha is less strong $(r=0.624)$, suggesting confounding variables. Poverty was identified as the most likely confounding variable. Income levels for both populations were low, with 49\% in Khayelitsha earning below R3000/month (187 Euro), and 37\% earning less than $964 \mathrm{GHc} /$ month (166 Euro) in Ahodwo. However, the 2016 upper-bound poverty line (UBPL) in Ghana was 1314 GHS [114], thus $47 \%$ of respondent households can be considered income-poor. In Khayelitsha, 70\% of households reported aggregate incomes below the South African 2018 UBPL of R1183/person [115]. Moreover, the PACSA annual food price report of 2017 indicates that the cost of a basic basket of food to feed a household of seven persons comes to R1912.98, thus roughly half that to feed the average Khayelitsha household. Consequently, about half of the population in the Khayelitsha sample would have to spend more than a third of household income just to satisfy basic food needs [116].

Noting the prevalence of poverty in the research sites, additional analysis was done cross-tabulating risk classes with the experience of income poverty documented by the Lived Poverty Index component of the survey [24]. Lack of access to cash incomes was a key issue $(46 \%$ in Khayelitsha and $20 \%$ in Ahodwo). Chi-test analysis yielded statistically significant $(p=0.005)$ differences in dietary risk distribution between households in Khayelitsha experiencing income deprivation and those who did not. Eighteen per cent fewer poor households exceeded obesogenic food consumption cutoffs than those who had not reported income deprivation. Cutoffs for protective food consumption were met by slightly fewer (6\%) income-deprived households than by non-deprived, likely because consumption levels were already low. This indicates that households experiencing income deprivation reduce consumption of obesogenic and, to a lesser extent, protective foods in favour of dietary staples. The Ahodwo sample showed a slight increase in consumption of protective foods among poor households $(7 \%)$ and a slight decrease in consumption of 
obesogenic. However, the association was not statistically significant $(p=0.54)$, suggesting that income poverty may have a more ambiguous impact on household food provisioning in Ahodwo.

\subsection{Mapping Obesogenic Food Provision and Consumption}

The following section presents maps reflecting food provision and consumption patterns. The food provision maps reflect the distribution of outlets belonging to the different risk classes. These are each juxtaposed with maps reflecting the distribution of household food environments in terms of the aggregate risk index.

\subsubsection{Food Provision and Consumption-Ahodwo}

The overview of food provision outlets in Ahodwo reveals a large number of outlets, concentrated along major roads and densely clustered around key intersections (Figure 9).

The Aggregate Consumption Index Map for Ahodwo (Figure 10) reveals no definite spatial clustering or pattern except for an apparent concentration of low risk, high protection diets around Kufuor I and Kufuor II streets and near the outlet clusters in the Northeast and Northwest corners of the sample frame (circled in red). The map reflects widespread prevalence of low-protection diets, with a fairly even distribution of low risk and high risk diets.

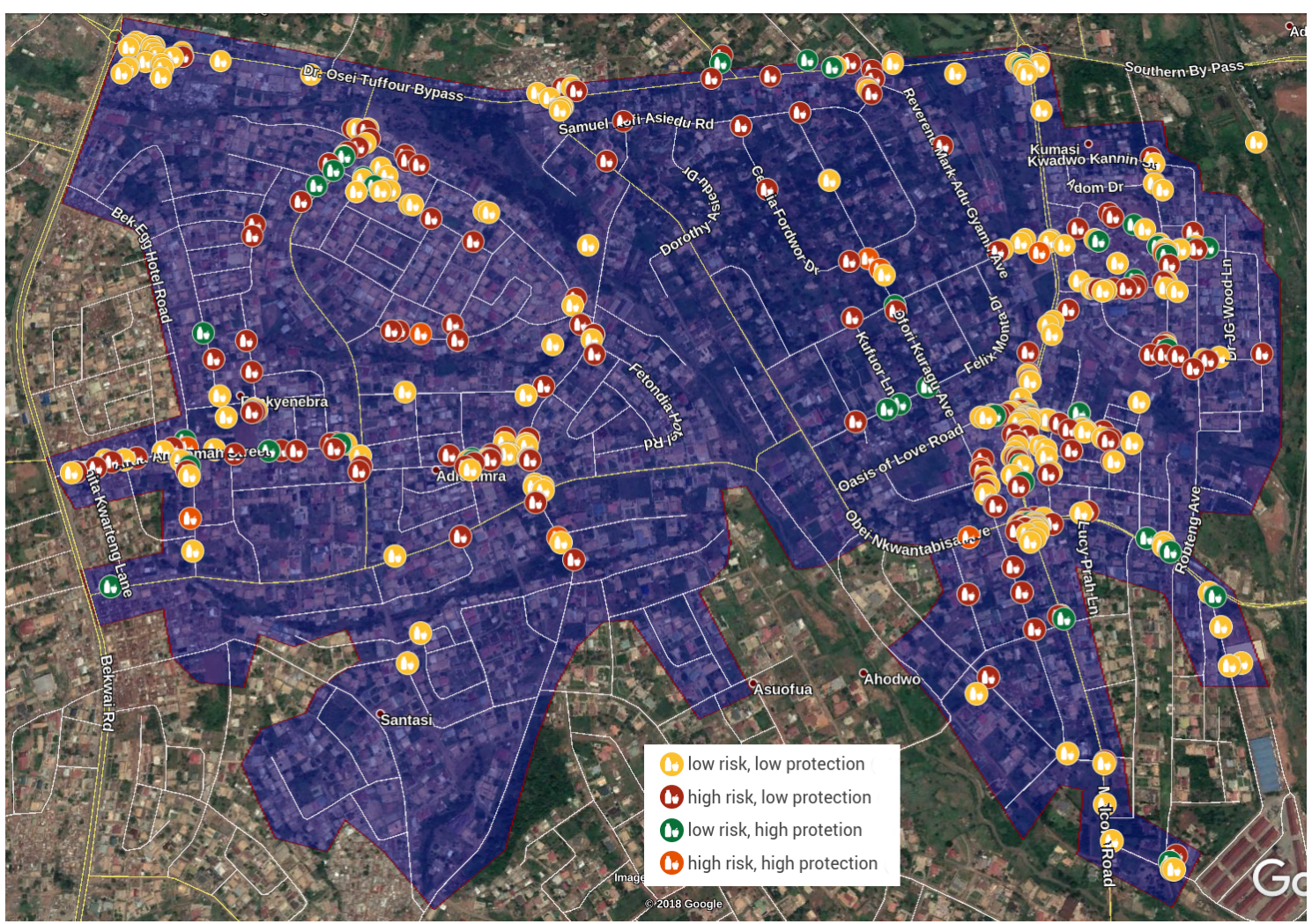

Figure 9. Ahodwo-food provision. 


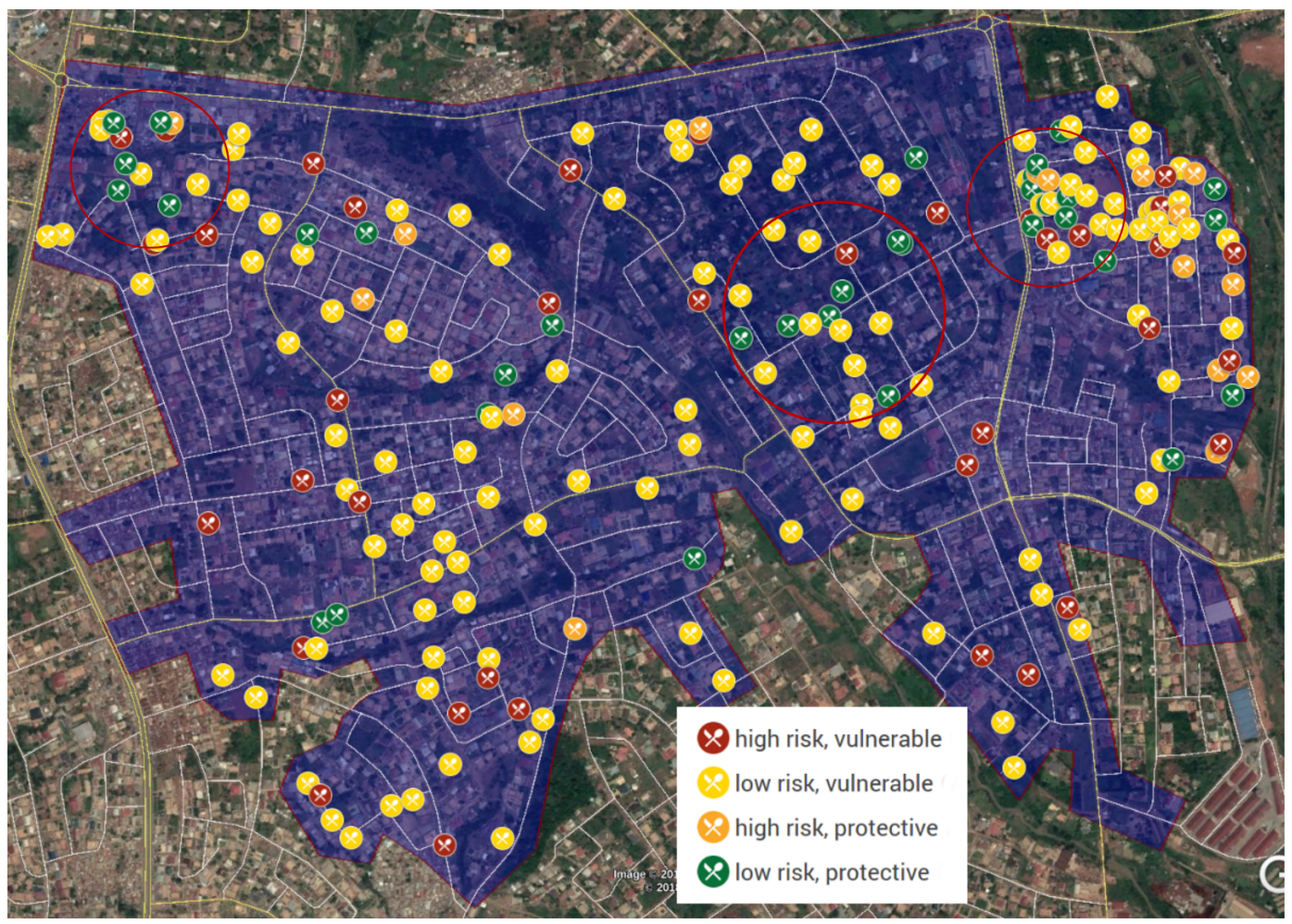

Figure 10. Ahodwo-aggregate food consumption.

\subsubsection{Food Provision and Consumption-Khayelitsha}

The food provision outlet map of Khayelitsha Site B (Figure 11) reveals a fairly low density of outlets, most clustered around the Nonkqubela shopping mall.

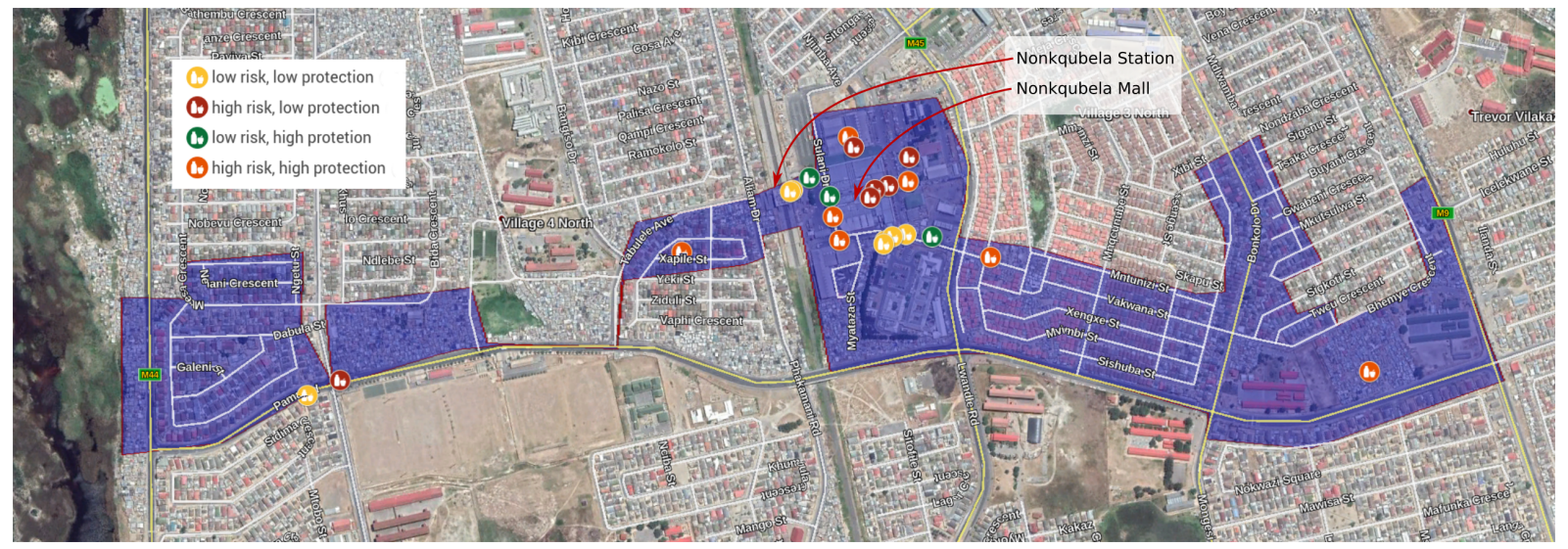

Figure 11. Khayelitsha Site B-Food provision.

The Makhaza area (Figure 12) shows dense clustering around the Makhaza shopping mall area, and a concentration of informal outlets along Ntlazane road in the informal settlement of Enkanini. 


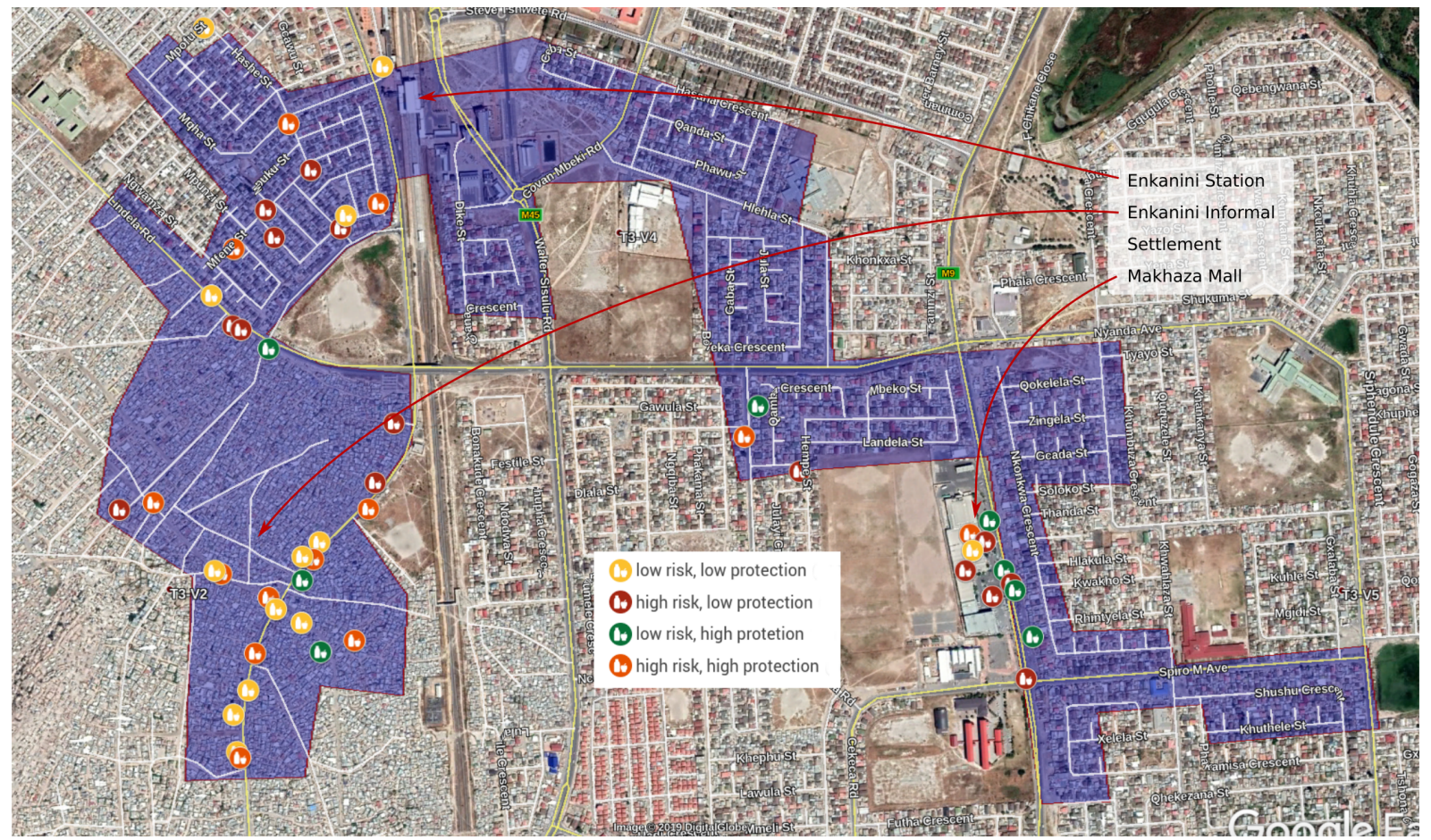

Figure 12. Makhaza-Enkanini-food provision.

In neither of these transects is there a clear spatial clustering of different food consumption risk categories (Figures 13 and 14).

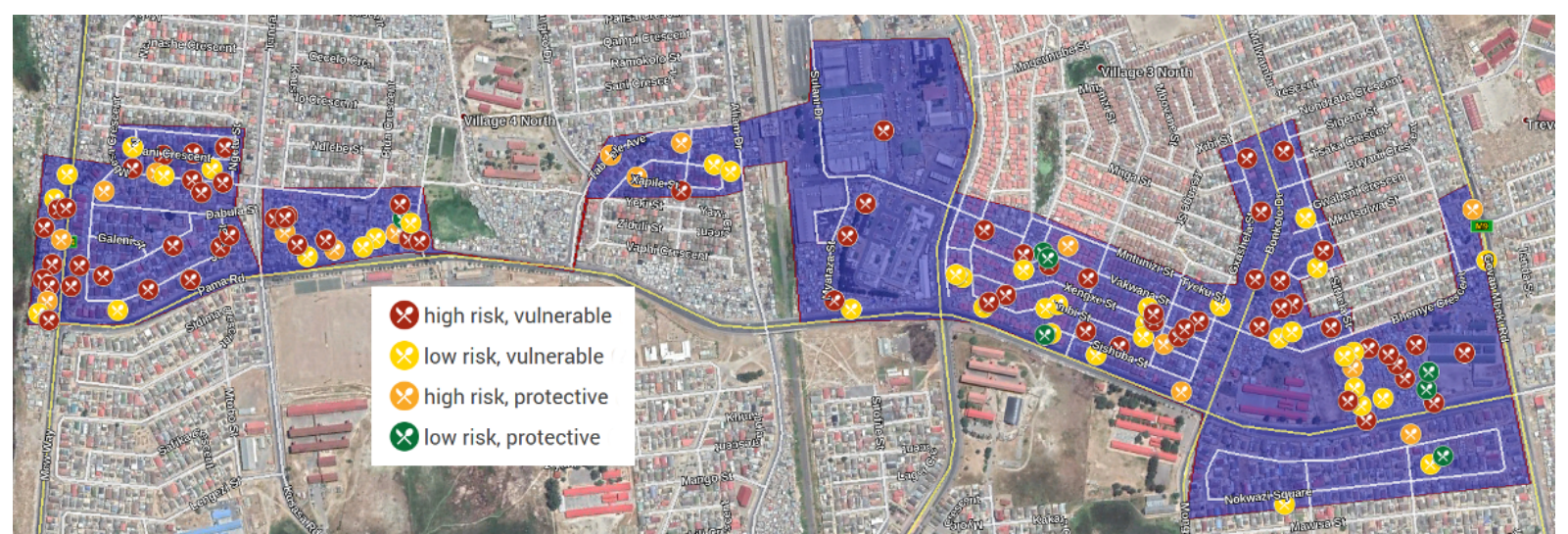

Figure 13. Map 7: Khayelitsha Site B—aggregate food consumption. 


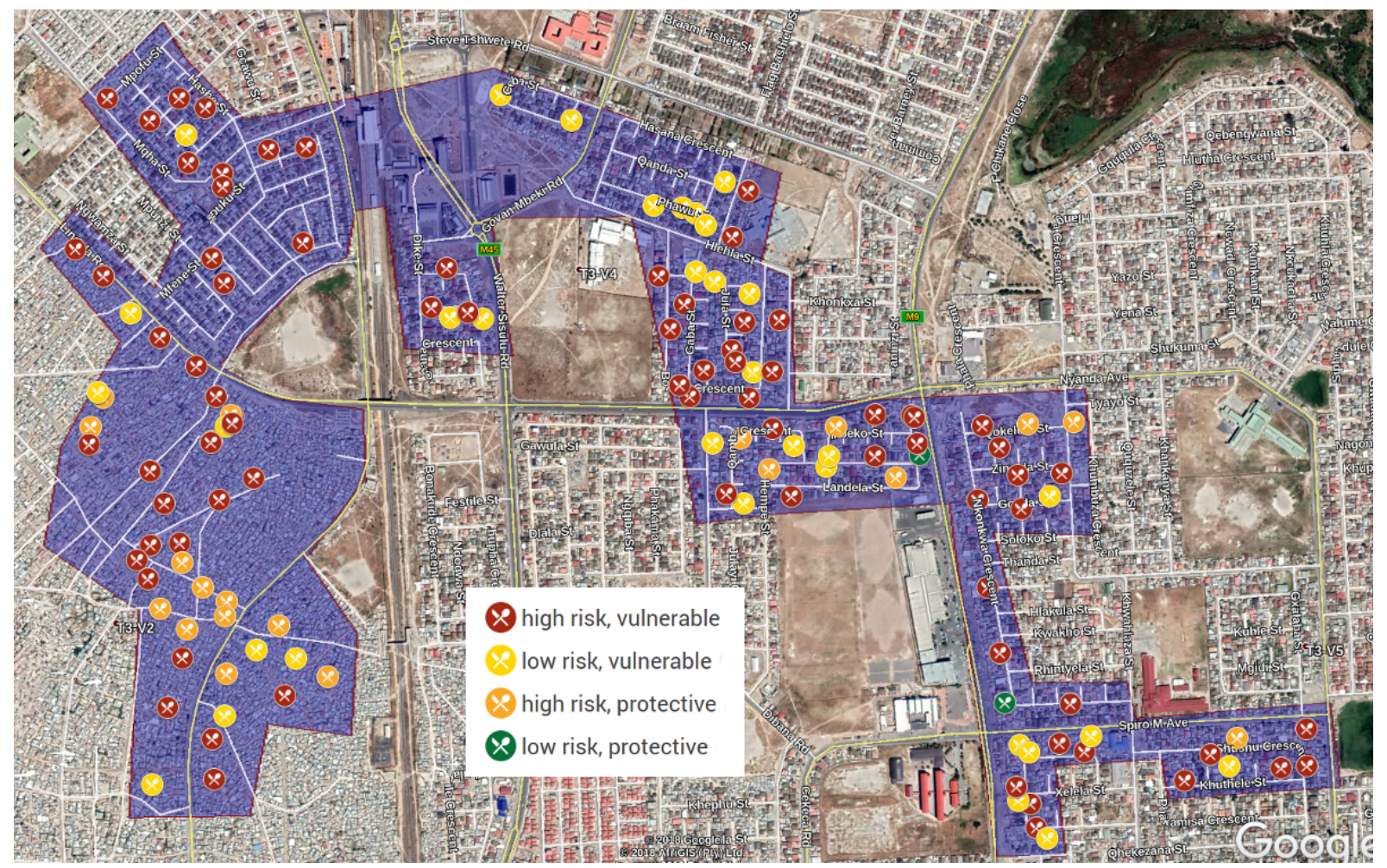

Figure 14. Map 8: Makhaza-Enkanini-aggregate food consumption.

\subsection{Summary}

In summary, household consumption patterns revealed that a large proportion of the Khayelitsha household food environments were high risk (i.e., frequent consumption of ultra-processed and obesogenic foods-71\%), but with low consumption of protective foods (only $16 \%$ meeting the threshold). The most commonly-consumed obesogenic foods in Khayelitsha were industrially produced bread, processed meat, sugar-sweetened beverages, and sugar (typically in hot beverages and added to porridge). These foods can be interpreted as a response to the poverty experienced, as they are typically cheap $[9,117,118]$, and do not require much preparation. The most commonly consumed protective foods were cooked vegetables.

Ahodwo household food environments differed slightly: Only $26 \%$ of the respondents reported risky diets, and only $23 \%$ met cutoffs for protective food consumption. While commercial bread and sugar-sweetened beverages were also frequently consumed, consumption of processed meat was less prevalent and confectionery was instead eaten more widely. Sugar was also among the obesogenic foods consumed regularly in Ahodwo. Protective foods commonly eaten included fish, cooked vegetables, as well as a slightly higher intake of fresh fruit and vegetables than in Khayelitsha (Figure 5). Consumption of low-risk, vulnerable diets is clearly higher, indicating a larger segment of the population relies on staple foods sourced from convenience stores and open-air vendors, while lacking other foods rich in micronutrients including fruits, vegetables and legumes.

Respondents' reports of their usual food sources show that in Khayelitsha, supermarkets play a key role in providing access to obesogenic foods. Roadside stalls, although often selling sweets on the side, are important sources of fresh produce in Khayelitsha. This confirms earlier AFSUN findings [37,78]. However, supermarkets are less important as a source of sugar-sweetened beverages. Instead, large proportions of the population access obesogenic foods such as commercial bread and sugar-sweetened beverages from small shops. People frequently access protective foods through roadside stalls and through local markets. 
The spatial patterning of the two research sites appears slightly different. In the more spatially extensive Ahodwo site, there was a higher number of food outlets which seem evenly dispersed except for dense clusters at busy intersections and markets. This may reflect the market culture of Kumasi, where outlets agglomerate in particular areas. By contrast, the transects surveyed in Khayelitsha suggest that in Site B food outlets are spatially clustered near the new malls and supermarkets, often close to public transport nodes and interchanges. In the Enkanini-Makhaza transect, there also appears to be a clustering of outlets along main access roads in the informal Enkanini settlement, providing convenient food access to residents far from the Makhaza mall. In Khayelitsha, the Site B and Makhaza malls are hotspots of obesogenic food provision, but also attract fruit and vegetable traders who provide access to healthier options. Mapping of aggregate food consumption risk indicated no obvious spatial clustering of risky household food intake in any of the research sites, nor any clear spatial relationship to food outlet location.

Outlets offering a variety of healthier food in Ahodwo were few and far between, and are clustered along Afua Ampomah street and Asante Frempong Avenue on the far eastern and western edge of the study area. However, many of these outlets also stock obesogenic food, and there is no obviously discernible pattern to the distribution of households consuming high levels of protective foods. In Khayelitsha, outlets providing access to healthier foods clustered around Site B mall, Ntlazane road and Makhaza mall. Supermarkets provide access to a range of healthier options, although of course they stock many obesogenic and ultra-processed foods, too.

\section{Discussion}

\subsection{Limitations}

Although the findings reveal information that speaks to previous research and has various implications for research and policy, the study has several limitations which constrain permissible inferences. The first is that approximately half of the food outlets mapped in Khayelitsha refused to participate in the survey (see below). In these cases, georeferences were recorded along with the store typology and a basic description (e.g., vegetable stall) to infer their level of nutritional risk. Secondly, the household survey did not document outshopping, i.e., that consumers travel to retail outlets outside of their local neighbourhoods to access food due to better prices, particular quality, or convenience along commuting routes. Thirdly, some informal outlets operate at times during which enumerators could not be in the field. Finally, the findings cannot be extrapolated as representative of broader consumption patterns in the immediate environments of the survey sample areas. Household scale of analysis means that internal dietary differences related to age, gender and power remain uncaptured in this particular analysis. Indicators of vulnerable household food environments are based on reported household food consumption, not individual food consumption, which will be published elsewhere.

\subsection{Key Insights}

The findings confirm the conclusions reached by several previous studies, namely that: (i) there is a co-existence of a diverse range of formal and informal food outlets [66,68,82,85,86]; (ii) obesogenic foods are widely prevalent and available $[65,87]$; (iii) supermarket expansion in particular is making ultra-processed and other obesogenic foods more accessible, although also offering access to a range of healthy options [25,38,46,85,87,117]; and (iv) there are high levels of consumption of obesogenic foods. This appears correlated with a local food geography which presents a large proportion of outlets with high prevalence of obesogenic foods.

Comparison also reveals important differences between the two sites. Both sites are urban and of comparable density, yet degrees of obesogenic risk in household and local food environments are 
clearly different. Firstly, the overall number of outlets per square kilometre is slightly higher in Ahodwo than in Khayelitsha, offering consumers a greater range of conveniently-located options, particularly of prepared foods. Secondly, the proportion of outlets stocking a range of obesogenic foods appears higher in Khayelitsha. Thirdly, from a spatial perspective, food outlets in Khayelitsha are far more densely clustered around the supermarkets and transport nodes, which likely influenced the location of the supermarkets. By comparison, in Ahodwo, although there is also some clustering around key intersections and open-air markets, there is a far broader distribution of food outlets spatially, making foods more easily accessible. However, the correlation between distributions of consumption and provision is far stronger in Ahodwo. Despite far greater relative availability of protective foods in Khayelitsha than Ahodwo, the household food environments suggested lower levels of protective food consumption in Khayelitsha (23\% Ahodwo; $16 \%$ Khayelitsha). This finding suggests that the local availability of protective foods alone plays only a partial role in promoting their consumption, and that other factors, such as cost, availability of refrigeration, and cost of cooking fuel [25,80,82,119-122], may constrain consumption of protective foods. In particular, poverty appears to play a strong role in influencing household food consumption in Khayelitsha. These findings have implications for the study of food environments, for our understanding of the nutrition transition and its drivers, and ultimately, for planning, policy and governance.

\subsection{Implications for Food Environment Research Methods}

The study results demonstrate that the widely accessible capabilities of smartphones, geo-location technologies, and online enumeration and data management technologies offer new opportunities to gather and evaluate data on informal food environments. However, the study also revealed limitations in the usefulness of such technology in areas of high poverty and inequality, where they present a safety risk to enumerators. By surveying two scales of food environment analysis (household and neighbourhood) and comparing emerging patterns, we were nevertheless able to identify key obesogenic and protective foods constituting household food environments. Moreover, statistical analysis based on the geographical density of outlet classes and the distribution of household risk classes revealed suggestive correlations and disjunctures. However, these quantitative and spatial perspectives should be complemented with qualitative and participatory approaches to document the experience of food environments by consumers and to interpret the findings of this survey.

\subsection{Implications for the Dietary Transition and Non-Communicable Disease}

The findings confirm that the dietary transition in LMICs [9] and Africa [13] is progressing apace, although further along in South Africa [14,15,26,91] than in West Africa [16]. Household food environments in Khayelitsha appear more severely obesogenic than in Ahodwo, mainly due to the higher consumption of risky foods and slightly lower consumption of protective foods. This appears to accord with the higher levels of obesity in the Western Cape than in Ashanti Region. The transition is often explained with reference to urbanisation and greater disposable incomes. Indeed, global sales of ultra-processed food correlate with higher levels of urbanisation and higher income countries. Nevertheless, sales growth of ultra-processed food over the last decades have been higher in low- and middle-income countries, compared with high-income ones [59]. The present study confirmed high levels of purchase and consumption of ultra-processed foods in urban settings in South Africa and Ghana. However, the higher prevalence of obesogenic food consumption in Khayelitsha in comparison with Ahodwo, where poverty is less extreme, calls the generic correlation of obesogenic food consumption with increased incomes into question. Nevertheless, within the Khayelitsha sample, households experiencing income deprivation consumed far less obesogenic foods. Therefore, while the availability of obesogenic foods in the Khayelitsha neighbourhood food environment appears to promote greater obesogenic household food 
consumption despite deeper levels of poverty than in Ahodwo, within the Khayelitsha population, higher incomes do appear to be correlated with greater obesogenic food consumption. The contradictions noted above suggest that other factors play a key role in explaining the disjunctures noted above, including levels of poverty, the structure of the food economy, as well as the spatial patterning of urban settlements.

These data suggest that a cautious and nuanced discussion of the role of supermarkets and their interaction with the informal economy in Khayelitsha and Ahodwo is necessary. While they provide access to obesogenic foods and may out-compete some small shops, supermarkets also provide access to legumes, fruit and vegetables which are healthier foods and attract footfall, which in turn draws fruit and vegetable traders. Transnational supermarket and mall expansion into the Ahodwo area has begun, evidenced by the nearby construction of a modern shopping mall including a Shoprite supermarket. This confirms that the South African supermarket retail model is being exported to other countries in the continent $[57,123]$. This may cause a contraction in the informal economy which could affect livelihoods and increase the availability of ultra-processed and obesogenic foods while making healthier options less attractive and less conveniently available. However, the informal food economy has proved resilient and adaptive, developing a complementary relationship with formal outlets [66,68,124]. Small shops in Khayelitsha may have adapted by specialising in the provision of regularly-consumed obesogenic foods such as commercial bread, SSBs, and confectionery, as well as grocery hampers composed of staples (not considered high-risk in this study as they are dietary staples). In Ahodwo, however, small shops also are a key source of healthier options.

\subsection{Implications for Food Environments Theory}

These findings are relevant to a more fundamental inquiry concerning the balance of forces between local food environments and endogenous household drivers (poverty and other forms of disadvantage), themselves conditioned by larger systemic and structural dynamics. The lack of clear geographical clustering of different household risk classes in relation to the location of food outlets suggests that, at the neighbourhood level, the aggregate density and composition of outlet types is more relevant than their location. The above-mentioned contradictions raise the question whether the greater consumption of protective food in Ahodwo is a result of the lack of big corporate penetration-or simply a reflection that this urban landscape, with less poverty than Khayelitsha, is one in which local demands can be met despite lower aggregate availability?

It thus appears that in Khayelitsha, household incomes are a stronger determinant of obesogenic food consumption patterns than local food availability—while most households are poor, the poorest tend to reduce consumption of ultra-processed foods and protective foods-their obesity risk derives from a reduction of protective foods and increased reliance on energy-dense staples. Poverty in Khayelitsha is reinforced spatially by the dislocation of Khayelitsha as a remote peri-urban dormitory settlement, a legacy of apartheid-era spatial planning, which traps the urban poor in areas far from job opportunities $[82,83,114]$. By comparison, Ahodwo is located fairly centrally in the Southeast of Kumasi metropolis, with a ubiquitous and vibrant street economy, presumably presenting more opportunities for equitable participation. This suggests that it is not urbanisation per se which is the issue, but that the spatial forms of urban spaces and the economic opportunities they offer which are perhaps more important.

\subsection{Implications for Planning, Governance and Policy}

Spatial analysis has enabled the identification of hotspots of obesogenic food provision, particularly around malls in Khayelitsha and busy intersections in Ahodwo, providing urban governance actors with potential points of geographic focus and leverage. This means that urban planners should consider the impacts of shopping malls and their immediate food environments on local livelihoods that property 
developers and commercial landlords be required to take into account the needs and opportunities presented by informal traders-especially fruit and vegetable stalls. Local government officials should not only adopt less obstructionist attitudes to street trade, but also consider how its role in providing access to fresh, whole foods can be supported in terms of land-use regulations, infrastructure and services. Interventions which make fresh, protective foods more cheaply and abundantly available to street traders may indirectly counter the tendency of the poorest households to economise by reducing their consumption of these foods. Infrastructure, regulation and social capital development supporting local aggregation and distribution and sale of fresh produce through cold chains, as well as the development of distributed micro-processing facilities may enhance the availability and lower costs of fresh and minimally-produced food.

The findings concerning small and informal shops suggest that particular attention should be paid to the regulation of upstream suppliers of obesogenic and ultra-processed foods as the small size, widespread distribution and large numbers of the retail outlets would make any form of direct regulation costly and logistically challenging. Although engagement with local trading associations may present opportunities to create awareness and develop adaptive multi-stakeholder governance approaches [97-99], the fractious nature of informal trade makes it challenging to find effective points of governance engagement and co-ordination [125]. Unless fresh, whole foods can be supplied more cheaply, it is therefore likely that traders will continue to respond to the demands of the urban poor for by providing cheap and convenient, but obesogenic foods. In Ahodwo, the development of large fresh-produce wholesale markets may support the provision of more affordable fresh produce through small shops and stalls.

The strong role which household poverty appears to play in constraining the consumption of protective foods suggests that regulatory intervention in local food environments alone may be of limited benefit unless accompanied by economic policy ensuring greater and more equitable economic participation, comprehensive social safety nets, and lower prices for fresh, healthy foods. At the local scale, the improvement and subsidisation of public transport could facilitate greater mobility essential to accessing economic opportunities.

\section{Conclusions}

The methodologies developed offer planners, activists and officials ways to visualise, engage with and interpret local food environments more concretely. The study reveals important insights into these particular food environments. The findings show that household food environments promoting obesity, more prevalent in Khayelitsha than in Ahodwo, appear correlated with neighbourhood food environments, which make obesogenic foods accessible and available, despite greater poverty in Khayelitsha. They also suggest that poverty is a powerful determinant not only of household consumption and purchasing but also of local food environments, thus suggesting a systemic feedback loop contrary to the direction of causality commonly implied in food environments theory. Making these "foodscapes" visible and legible may enable state and civil society agents to frame them as more concrete objects of local governance discourse. This is essential to galvanise the "will to transform" them [126,127]. In light of the above interpretation of the findings, however, governance of food environments may offer only limited leverage to address obesity in the face of systemic poverty and inequality. It cannot substitute for more fundamental engagement with socio-economic and spatial drivers of obesity which transcends a narrow focus on food. 
Author Contributions: This paper is based on research conducted by the ROFE team. The authors listed made the following contributions: Conceptualisation, F.K., E.C.S., R.A.A., A.M.T., C.A., A.D.T., R.A. and D.S.; Data curation, F.K.; Formal analysis, F.K.; Funding acquisition, E.C.S., R.A.A., A.D.T. and D.S.; Investigation, F.K., E.C.S., R.A.A., C.A., L.N.E.A. and N.A.F.A.; Methodology, F.K., E.C.S., R.A.A., A.M.T., D.N., C.A., L.N.E.A., J.-C.M., R.A. and D.S.; Project administration, F.K., E.C.S. and L.N.E.A.; Resources, F.K.; Software, F.K. and A.M.T.; Supervision, E.C.S., R.A.A., A.M.T., J.-C.M. and D.S.; Validation, E.C.S., R.A.A., A.M.T., D.N., C.A., L.N.E.A., N.A.F.A., J.-C.M., R.A. and D.S.; Visualisation, F.K.; Writing—original draft, F.K.; and Writing-review and editing, E.C.S., R.A.A., A.M.T., D.N., L.N.E.A., N.A.F.A., J.-C.M., A.D.T. and D.S.

Funding: This research was supported by grant No. 108425-001 from the International Development Research Center, Canada. The funders had no role in study design, data collection and analysis, decision to publish, or preparation of the manuscript. URL: https://www.idrc.ca/en/project/researching-obesogenic-urban-food-environment-its-driversand-potential-policy-levers-south.

Acknowledgments: The researchers would like to acknowledge the three anonymous reviewers, whose comments have helped refine this paper.

Conflicts of Interest: The authors declare no conflict of interest. The funders had no role in the design of the study; in the collection, analyses, or interpretation of data; in the writing of the manuscript, or in the decision to publish the results.

\section{References}

1. Holt Giménez, E.; Shattuck, A. Food crises, food regimes and food movements: Rumblings of reform or tides of transformation? J. Peasant Stud. 2011, 38, 109-144. [CrossRef]

2. Campbell, H. Breaking new ground in food regime theory: Corporate environmentalism, ecological feedbacks and the 'food from somewhere' regime? Agric. Hum. Values 2009, 26, 309-319. [CrossRef]

3. McMichael, P. A food regime analysis of the 'world food crisis'. Agric. Hum. Values 2009, 26, 281-295. [CrossRef]

4. Haysom, G. Food and the City: Urban Scale Food System Governance. Urban Forum 2015, 26, 263-281. [CrossRef]

5. Battersby, J. Food System transformation in the Absence of Food System Planning: The Case of Supermarket and Shopping Mall Retail Expansion in Cape Town, South Africa. Built Environ. 2017, 43, 417-430. [CrossRef]

6. Drewnowski, A.; Popkin, B.M. The nutrition transition: New trends in the global diet. Nutr. Rev. 1997, 55, 31-43. [CrossRef]

7. Popkin, B.M. Urbanization, Lifestyle Changes and the Nutrition Transition. World Dev. 1999, $27,1905-1916$. [CrossRef]

8. Popkin, B.M.; Gordon-Larsen, P. The nutrition transition: Worldwide obesity dynamics and their determinants. Int. J. Obes. Relat. Metab. Disord. 2004, 28 (Suppl. 3), S2-S9. [CrossRef]

9. Popkin, B.M.; Adair, L.S.; Ng, S.W. Global nutrition transition and the pandemic of obesity in developing countries. Nutr. Rev. 2012, 70, 3-21. [CrossRef]

10. Popkin, B.M.; Slining, M.M. New dynamics in global obesity facing low- and middle-income countries. Obes. Rev. 2013, 14 (Suppl. 2), 11-20. [CrossRef]

11. Doak, C.M.; Adair, L.S.; Bentley, M.; Monteiro, C.; Popkin, B.M. The dual burden household and the nutrition transition paradox. Int. J. Obes. 2005, 29, 129-136. [CrossRef]

12. Stringhini, S.; Carmeli, C.; Jokela, M.; Avendaño, M.; Muennig, P.; Guida, F.; Ricceri, F.; d'Errico, A.; Barros, H.; Bochud, M.; et al. Socioeconomic status and the $25 \times 25$ risk factors as determinants of premature mortality: A multicohort study and meta-analysis of 1.7 million men and women. Lancet 2017, 389, 1229-1237. [CrossRef]

13. Vorster, H.H.; Kruger, A.; Margetts, B.M. The nutrition transition in Africa: Can it be steered into a more positive direction? Nutrients 2011, 3, 429-441. [CrossRef]

14. Steyn, N.P.; McHiza, Z.J. Obesity and the nutrition transition in Sub-Saharan Africa. Ann. N. Y. Acad. Sci. 2014, 1311, 88-101. [CrossRef]

15. Abrahams, Z.; McHiza, Z.; Steyn, N.P. Diet and mortality rates in Sub-Saharan Africa: Stages in the nutrition transition. BMC Public Health 2011, 11, 801. [CrossRef]

16. Bosu, W.K. An overview of the nutrition transition in West Africa: Implications for non-communicable diseases. Proc. Nutr. Soc. 2015, 74, 466-477. [CrossRef] 
17. Ofori-Asenso, R.; Agyeman, A.A.; Laar, A.; Boateng, D. Overweight and obesity epidemic in Ghana-A systematic review and meta-analysis. BMC Public Health 2016, 16, 1239. [CrossRef]

18. South African National Department of Health; Statistics South Africa; South African Medical Research Council; ICF. South Africa Demographic and Health Survey 2016: Key Indicator Report. Technical Report. 2017. Available online: http:/ / www.health.gov.za/index.php/2014-03-17-09-09-38/strategic-documents/category/536-southafrican-demographic-health-survey?download=3311:key-findings-sadhs-2016-final-compressed (accessed on 21 May 2019).

19. Service, G.S. Ghana Multiple Indicator Cluster Survey with an Enhanced Malaria Module and Biomarker. Technical Report. 2011. Available online: https://www.unicef.org/ghana/Ghana_MICS_Final.pdf (accessed on 21 May 2019)

20. Mattah, A.; Akpakli, J. Effects of the Global Financial Crisis on the Food Security of Poor Urban Households. Case Study Accra, Ghana, Technical Report. 2010. Available online: https://www.ruaf.org/sites/default/files / Case\%20study\%20Accra\%20report.pdf (accessed on 21 May 2019).

21. Shisana, O.; Labadarios, D.; Rehle, T.; Simbayi, L.; Zuma, K.; Dhansay, A.; Reddy, P.; Parker, W.; Hoosain, E.; Naidoo, P.; et al. South African National Health and Nutrition Examination Survey (SANHANES-1), Technical Report. 2013. Available online: http://www.hsrc.ac.za/uploads/pageNews/72/SANHANES-launch\% 20edition\%20(online\%20version).pdf (accessed on 21 May 2019).

22. Said-Mohamed, R.; Micklesfield, L.K.; Pettifor, J.M.; Norris, S.A. Has the prevalence of stunting in South African children changed in 40 years? A systematic review. BMC Public Health 2015, 15, 534. [CrossRef]

23. Muzigaba, M.; Puoane, T.; Sanders, D. The paradox of undernutrition and obesity in South Africa: A contextual overview of food quality, access and availability in the new democracy. In Food Poverty and Insecurity: International Food Inequalities; Caraher, M., Coveney, J., Eds.; Food Policy; Springer International Publishing: Cham, Switzerland, 2016; pp. 31-41,

24. Mattes, R. The Material and Political Bases of Lived Poverty in Africa: Insights from the Afrobarometer. In Barometers of Quality of Life around the Globe; Møller, V., Huschka, D., Michalos, A.C., Eds.; Springer: Dordrecht, The Netherlands, 2009; pp. 161-185.

25. Frayne, B.; Crush, J.; McLachlan, M. Urbanization, nutrition and development in Southern African cities. Food Secur. 2014, 6, 101-112. [CrossRef]

26. Bourne, L.T.; Lambert, E.V.; Steyn, K. Where does the black population of South Africa stand on the nutrition transition? Public Health Nutr. 2002, 5, 157-162. [CrossRef]

27. Mayosi, B.M.; Flisher, A.J.; Lalloo, U.G.; Sitas, F.; Tollman, S.M.; Bradshaw, D. The burden of non-communicable diseases in South Africa. Lancet 2009, 374, 934-947. [CrossRef]

28. Agyei-Mensah, S.; de Graft Aikins, A. Epidemiological transition and the double burden of disease in Accra, Ghana. J. Urban Health 2010, 87, 879-897. [CrossRef]

29. Adom, P. Determinants of food availability and access in Ghana: What can we learn beyond the regression results? Stud. Agric. Econ. 2014, 116, 153-164. [CrossRef]

30. Darfour, B.; Rosentrater, K. Agriculture and food security in ghana. In Proceedings of the 2016 American Society of Agricultural and Biological Engineers (ASABE) International Meeting, Orlando, FL, USA, 17-20 July 2016. [CrossRef]

31. Hjelm, L.; Dasori, W. Ghana Comprehensive Food Security \& Vulnerability Analysis. Technical Report, 2012. Available online: https://documents.wfp.org/stellent/groups/public/documents/ena/wfp257009.pdf?_ga= 2.27925884.1549009827.1558443370-396782588.1558443370 (accessed on 21 May 2019)

32. Maxwell, D.; Levin, C.; Armar-Klemesu, M.; Ruel, M.; Morris, S.; Ahiadeke, C. Urban Livelihoods and Food and Nutrition Security in Greater Accra, Ghana. Technical Report. 2000. Available online: https://www.who.int/ nutrition/publications/WHO_multicountry_\%20study_Ghana.pdf (accessed on 21 May 2019)

33. Lopéz-Carr, A.C.; Weeks, J.; Lopéz-Carr, D. Examining the Role of Urban Food Spaces: A Neighborhood Level Exploration of Food Geographies in Accra, Ghana; ETH: Zurich, Switzerland, 2010.

34. Codjoe, S.N.A.; Okutu, D.; Abu, M. Urban household characteristics and dietary diversity: An analysis of food security in Accra, Ghana. Food Nutr. Bull. 2016, 37, 202-218. [CrossRef] 
35. Devas, N. City governance and poverty: The case of Kumasi. Environ. Urban 2000, 12, 123-136. [CrossRef]

36. Prain, G. Effects of the Global Financial Crisis on the Food Security of Poor Urban Households; Synthesis Report on Five City Case Studies; Synthesis Report; RUAF: Leusden, The Netherlands, 2010.

37. Frayne, B.; Pendleton, W.; Crush, J.; Acquah, B.; Battersby-Lennard, J.; Bras, E.; Chiweza, A.; Dlamini, T.; Fincham, R.; Kroll, F.; et al. The State of Urban Food Insecurity in Southern Africa. AFSUN Urban Food Security Series. 2010. Available online: http:/ / www.afsun.org/wp-content/uploads/2013/09/AFSUN_2.pdf (accessed on 21 May 2019)

38. Crush, J.; Frayne, B. Supermarket expansion and the informal food economy in southern african cities: Implications for urban food security. J. S. Afr. Stud. 2011, 37, 781-807. [CrossRef]

39. Battersby, J. The State of Urban Food Insecurity in Cape Town; Urban Food Security Series; Queen's University and AFSUN: Kingston, ON, Canada; Cape Town, South Africa, 2011. Available online: https://www. google.com.tw / url?sa=t\&rct=j\&q=\&esrc=s\&source=web\&cd=1\&ved=2ahUKEwi29fSS5r3jAhVPG6YKHYED-cQFjAAegQIABAC\&url=http \%3A\%2F\%2Fwww.afsun.org\%2Fwp-content $\% 2 F u p l o a d s \% 2 F 2013 \% 2 F 09 \%$ 2FAFSUN_11.pdf\&usg=AOvVaw3CWbyA289GpcqPCvi3Mlwp (accessed on 18 July 2019).

40. Kennedy, G.; Nantel, G.; Shetty, P.; Food and Agriculture Organization of the United Nations. Globalization of Food Systems in Developing Countries: Impact on Food Security and Nutrition; FAO Food Nutr Paper; FAO: Rome, Italy, 2004; Volume 83, pp. 1-300.

41. Ericksen, P.J. Conceptualizing food systems for global environmental change research. Glob. Environ. Chang. 2008, 18, 234-245. [CrossRef]

42. Ingram, J. A food systems approach to researching food security and its interactions with global environmental change. Food Secur. 2011, 3, 417-431. [CrossRef]

43. Igumbor, E.U.; Sanders, D.; Puoane, T.R.; Tsolekile, L.; Schwarz, C.; Purdy, C.; Swart, R.; Durão, S.; Hawkes, C. "Big food", the consumer food environment, health, and the policy response in South Africa. PLoS Med. 2012, 9, e1001253. [CrossRef]

44. Thow, A.M.; Sanders, D.; Drury, E.; Puoane, T.; Chowdhury, S.N.; Tsolekile, L.; Negin, J. Regional trade and the nutrition transition: Opportunities to strengthen NCD prevention policy in the Southern African Development Community. Glob. Health Action 2015, 8, 28338. [CrossRef]

45. Schram, A.; Labonté, R.; Sanders, D. Urbanization and international trade and investment policies as determinants of noncommunicable diseases in Sub-Saharan Africa. Prog. Cardiovasc. Dis. 2013, 56, $281-301$. [CrossRef]

46. Hawkes, C. Dietary implications of supermarket development: A global perspective. Dev. Policy Rev. 2008, 26, 657-692. [CrossRef]

47. Hruby, A.; Manson, J.E.; Qi, L.; Malik, V.S.; Rimm, E.B.; Sun, Q.; Willett, W.C.; Hu, F.B. Determinants and consequences of obesity. Am. J. Public Health 2016, 106, 1656-1662. [CrossRef]

48. Mozaffarian, D.; Hao, T.; Rimm, E.B.; Willett, W.C.; Hu, F.B. Changes in diet and lifestyle and long-term weight gain in women and men. N. Engl. J. Med. 2011, 364, 2392-2404. [CrossRef]

49. Malik, V.S.; Li, Y.; Tobias, D.K.; Pan, A.; Hu, F.B. Dietary protein intake and risk of type 2 diabetes in US men and women. Am. J. Epidemiol. 2016, 183, 715-728. [CrossRef]

50. Malik, V.S.; Willett, W.C.; Hu, F.B. Global obesity: Trends, risk factors and policy implications. Nat. Rev. Endocrinol. 2013, 9, 13-27. [CrossRef]

51. Mozaffarian, D. Dietary and policy priorities for cardiovascular disease, diabetes, and obesity: A comprehensive review. Circulation 2016, 133, 187-225. [CrossRef]

52. Forouhi, N.G.; Krauss, R.M.; Taubes, G.; Willett, W. Dietary fat and cardiometabolic health: Evidence, controversies, and consensus for guidance. BMJ 2018, 361, k2139. [CrossRef]

53. Willett, W.C. Dietary fat plays a major role in obesity: No. Obes. Rev. 2002, 3, 59-68. [CrossRef]

54. de Souza, R.J.; Mente, A.; Maroleanu, A.; Cozma, A.I.; Ha, V.; Kishibe, T.; Uleryk, E.; Budylowski, P.; Schünemann, H.; Beyene, J.; et al. Intake of saturated and trans unsaturated fatty acids and risk of all cause mortality, cardiovascular disease, and type 2 diabetes: Systematic review and meta-analysis of observational studies. BMJ 2015, 351, h3978. [CrossRef] 
55. Hu, F.B.; van Dam, R.M.; Liu, S. Diet and risk of Type II diabetes: The role of types of fat and carbohydrate. Diabetologia 2001, 44, 805-817. [CrossRef]

56. Bhupathiraju, S.N.; Tobias, D.K.; Malik, V.S.; Pan, A.; Hruby, A.; Manson, J.E.; Willett, W.C.; Hu, F.B. Glycemic index, glycemic load, and risk of type 2 diabetes: Results from 3 large US cohorts and an updated meta-analysis. Am. J. Clin. Nutr. 2014, 100, 218-232. [CrossRef]

57. Hall, R.; Cousins, B. Exporting contradictions: The expansion of South African agrarian capital within Africa. Globalizations 2018, 15, 12-31. [CrossRef]

58. Canella, D.S.; Levy, R.B.; Martins, A.P.B.; Claro, R.M.; Moubarac, J.C.; Baraldi, L.G.; Cannon, G.; Monteiro, C.A. Ultra-processed food products and obesity in Brazilian households (2008-2009). PLoS ONE 2014, 9, e92752. [CrossRef]

59. Juul, F.; Hemmingsson, E. Trends in consumption of ultra-processed foods and obesity in Sweden between 1960 and 2010. Public Health Nutr. 2015, 18, 3096-3107. [CrossRef]

60. da Costa Louzada, M.L.; Baraldi, L.G.; Steele, E.M.; Martins, A.P.B.; Canella, D.S.; Moubarac, J.C.; Levy, R.B.; Cannon, G.; Afshin, A.; Imamura, F.; et al. Consumption of ultra-processed foods and obesity in Brazilian adolescents and adults. Prev. Med 2015, 81, 9-15. [CrossRef]

61. Mendonça, R.D.; Pimenta, A.M.; Gea, A.; de la Fuente-Arrillaga, C.; Martinez-Gonzalez, M.A.; Lopes, A.C.S.; Bes-Rastrollo, M. Ultraprocessed food consumption and risk of overweight and obesity: The University of Navarra Follow-Up (SUN) cohort study. Am. J. Clin. Nutr. 2016, 104, 1433-1440. [CrossRef]

62. PAHO. Ultra-Processed Food and Drink Products in Latin America: Trends, Impact on Obesity, Policy Implications; Technical Report; PAHO: Washington, DC, USA, 2015.

63. Weatherspoon, D.D.; Reardon, T. The rise of supermarkets in Africa: Implications for agrifood systems and the rural poor. Dev. Policy Rev. 2003, 21, 333-355. [CrossRef]

64. Monteiro, C.A.; Moubarac, J.C.; Cannon, G.; Ng, S.W.; Popkin, B. Ultra-processed products are becoming dominant in the global food system. Obes. Rev. 2013, 14 Suppl. 2), 21-28. [CrossRef]

65. Andam, K.S.; Tschirley, D.; Asante, S.B.; Al-Hassan, R.M.; Diao, X. The transformation of urban food systems in Ghana: Findings from inventories of processed products. Outlook Agric. 2018, 47, 003072701878591. [CrossRef]

66. Peyton, S.; Moseley, W.; Battersby, J. Implications of supermarket expansion on urban food security in Cape Town, South Africa. Afr. Geogr. Rev. 2015, 34, 36-54. [CrossRef]

67. Greenberg, S. Corporate power in the agro-food system and the consumer food environment in South Africa. J. Peasant Stud. 2017, 44, 467-496. [CrossRef]

68. Battersby, J.; Crush, J. Africa' urban food deserts. Urban Forum 2014, 25, 143-151. [CrossRef]

69. Greenberg, S. Contesting the Food System in South Africa: Issues and Opportunities. Research Report. 2010. Available online: http:/ / repository.uwc.ac.za/xmlui/bitstream/handle/10566/572/RR42.pdf? sequence=1\& isAllowed =y (accessed on 21 May 2019)

70. Charman, A.; Petersen, L.; Piper, L. From local survivalism to foreign entre-preneurship: The transformation of the spaza sector in Delft, Cape Town1. Transformation 2012, 78, 47-73. [CrossRef]

71. Ecker, O.; Breisinger, C. The Food Security System: A New Conceptual Framework, Technical Report. 2012. Available online: http:/ / www.ifpri.org/cdmref/p15738coll2/id/126837/filename/127048.pdf (accessed on 21 May 2019)

72. Glanz, K.; Sallis, J.F.; Saelens, B.E.; Frank, L.D. Healthy nutrition environments: Concepts and measures. Am. J. Health Promot. 2005, 19. [CrossRef]

73. Turner, C.; Aggarwal, A.; Walls, H.; Herforth, A.; Drewnowski, A.; Coates, J.; Kalamatianou, S.; Kadiyala, S. Concepts and critical perspectives for food environment research: A global framework with implications for action in low- and middle-income countries. Glob. Food Sec. 2018, 18, 93-101. [CrossRef]

74. Herforth, A.; Ahmed, S. The food environment, its effects on dietary consumption, and potential for measurement within agriculture-nutrition interventions. Food Secur. 2015, 7, 505-520. [CrossRef]

75. Losch, B. The Need for a Paradigm Shift towards Territorial Development in Sub-Saharan Africa; Working Paper Series; RIMISP, Santiago, Chile, 2016. 
76. Losch, B. Can We Still Only Think 'Rural'? Bridging the rural-urban divide for rural transformation in a globalized world. Development 2015, 58, 169-176. [CrossRef]

77. Chen, M. The Informal Economy: Definitions, Theories and Policies. Working Paper. 2012. Available online: http: //www.wiego.org/sites/default/files/publications/files/Chen_WIEGO_WP1.pdf (accessed on 21 May 2019).

78. Crush, J.; Hovorka, A.; Tevera, D. Food security in Southern African cities. Prog. Dev. Stud. 2011, 11, $285-305$. [CrossRef]

79. Rudolph, M.; Kroll, F.; Ruysenaar, S.; Dlamini, T. The State of Food Insecurity in Johannesburg, Research Report. 2012. Available online: http:/ / www.afsun.org/wp-content/uploads/2013/09/AFSUN_12.pdf (accessed on 21 May 2019).

80. Skinner, C.; Haysom, G. The Informal Sector' Role in Food Security: A Missing Link in Policy Debates? Working Paper, Cape Town. 2016. Available online: https://www.africaportal.org/documents/16322/WP44_ SkinnerHaysom.pdf (accessed on 21 May 2019).

81. Even-Zahav, E.; Kelly, C. Systematic review of the literature on 'informal economy' and 'food security': South Africa, 2009-2014. Working Paper. 2016. Available online: https:/ / www.africaportal.org/documents / 15874/WP35_Even-Zahav_final.pdf (accessed on 21 May 2019).

82. Battersby, J.; Marshak, M.; Mngqibisa, N. Mapping the invisible: The informal food economy of Cape Town, South Africa. Technical Report. 2016. Available online: http:/ /www.afsun.org/wp-content/uploads/2017/06/ AFSUN24.pdf (accessed on 21 May 2019).

83. Sinclair-Smith, K.; Turok, I. The changing spatial economy of cities: An exploratory analysis of Cape Town. Dev. S. Afr. 2012, 29, 391-417. [CrossRef]

84. Turok, I.; Borel-Saladin, J. Is urbanisation in South Africa on a sustainable trajectory? Dev. S. Afr. 2014, 31, 675-691. [CrossRef]

85. Meng, T.; Florkowskib, W.; Sarpongc, D.; Chinn, M.; Resurreccione, A. Consumer's Food Shopping Choice in Ghana: Supermarket or Traditional Outlets? Supermarket or Traditional Outlets? IFAMA 2014, 17, $107-130$.

86. Davis, J. Selling Wares on the Streets of Accra: A Case Study of Street Hawkers in Ghana's Capital. Focus Geogr. 2008, 51, 32-37, [CrossRef]

87. Dake, F.A.A.; Thompson, A.L.; Ng, S.W.; Agyei-Mensah, S.; Codjoe, S.N.A. The Local Food Environment and Body Mass Index among the Urban Poor in Accra, Ghana. J. Urban Health 2016, 93, 438-455. [CrossRef]

88. Hughes, F.; Adu-Gyamfi, A.; Appiah, V. Microbiological and Parasitological Quality of Local Beef Retailed in Accra and Radiation Sensitivity of Salmonella sp. Int. J. Curr. Microbiol. App. Sci. 2015, 4, 86-96.

89. Duedu, K.O.; Yarnie, E.A.; Tetteh-Quarcoo, P.B.; Attah, S.K.; Donkor, E.S.; Ayeh-Kumi, P.F. A comparative survey of the prevalence of human parasites found in fresh vegetables sold in supermarkets and open-aired markets in Accra, Ghana. BMC Res Notes 2014, 7, 836. [CrossRef]

90. Bempah, C.K.; Donkor, A.K. Pesticide residues in fruits at the market level in Accra Metropolis, Ghana, a preliminary study. Environ. Monit. Assess. 2011, 175, 551-561. [CrossRef]

91. Steyn, N.P.; Labadarios, D.; Nel, J.H. Factors which influence the consumption of street foods and fast foods in South Africa-A national survey. Nutr J 2011, 10, 104. [CrossRef]

92. Libman, K.; Freudenberg, N.; Sanders, D.; Puoane, T.; Tsolekile, L. The role of urban food policy in preventing diet-related non-communicable diseases in Cape Town and New York. Public Health 2015, 129, 327-335. [CrossRef]

93. Smit, W. Urban governance and urban food systems in Africa: Examining the linkages. Cities 2016, 58, 80-86. [CrossRef]

94. Rhodes, R.A.W. The New Governance: Governing without Government. Political Stud. 1996, 44, 652-667. [CrossRef]

95. Smit, W.; de Lannoy, A.; Dover, R.V.H.; Lambert, E.V.; Levitt, N.; Watson, V. Making unhealthy places: The built environment and non-communicable diseases in Khayelitsha, Cape Town. Health Place 2016, 39, 196-203. [CrossRef]

96. Jessop, B. The Governance of Complexity and the Complexity of Governance: Preliminary Remarks on some Problems and Limits of Economic Guidance. Technical Report. 2003. Available online: https://www.lancaster. ac.uk/fass/resources/sociology-online-papers/papers/jessop-governance-of-complexity.pdf (accessed on 21 May 2019). 
97. Candel, J.J.L. Food security governance: A systematic literature review. Food Secur. 2014, 6, 585-601. [CrossRef]

98. Pereira, L.; Drimie, S. Governance arrangements for the future food system: Addressing complexity in South Africa. Environ. Sci. Policy Sustain. Dev. 2016, 58, 18-31. [CrossRef]

99. Pereira, L.M.; Ruysenaar, S. Moving from traditional government to new adaptive governance: The changing face of food security responses in South Africa. Food Sec. 2012, 4, 41-58. [CrossRef]

100. Termeer, C.J.; Drimie, S.; Ingram, J.; Pereira, L.; Whittingham, M.J. A diagnostic framework for food system governance arrangements: The case of South Africa. NJAS-Wagening. J. Life Sci. 2017, 84, 85-93. [CrossRef]

101. Pothukuchi, K.; Kaufman, J.L. Kameshwari Pothukuchi \& Jerome L. Kaufman, Placing the Food System on the Urban Agenda: The Role of Municipal Institutions in Food Systems Planning-PhilPapers. 1999. Available online: http:/ / archive.clas.wayne.edu/Multimedia/seedwayne/files/kami/1_5AHV.pdf (accessed on 21 May 2019).

102. Foucault, M. Security, Territory, Population; Palgrave: Macmillan, UK, 2009.

103. Haysom, G.; Tawodzera, G. 'Measurement drives diagnosis and response': Gaps in transferring food security assessment to the urban scale. Food Policy 2018, 74, 117-125. [CrossRef]

104. Scott, J. Seeing Like a State. How Certain Schemes to Improve the Human Condition Have Failed; Yale University Press: Yale, CT, USA, 1999.

105. Stevens, A. Telling Policy Stories: An Ethnographic Study of the Use of Evidence in Policy-making in the UK. J. Soc. Policy 2011, 40, 237-255. [CrossRef]

106. Du Toit, A. Making Sense of 'Evidence'. Notes on the Discursive Politics of Research and Pro-Poor Policy Making; Working Paper; Institute for Poverty, Land and Agrarian Studies (PLAAS): Bellville, South Africa, 2012.

107. Petersen, L.M.; Charman, A.J.E. The scope and scale of the informal food economy of South African urban residential townships: Results of a small-area micro-enterprise census. Dev. S. Afr. 2017, 1-23. [CrossRef]

108. Turok, I.; Watson, V. Divergent development in South African cities: Strategic challenges facing Cape Town. Urban Forum 2001, 12, 119-138. [CrossRef]

109. Arambepola, C.; Scarborough, P.; Rayner, M. Validating a nutrient profile model. Public Health Nutr. 2008, 11, 371-378. [CrossRef]

110. Scarborough, P.; Rayner, M.; Stockley, L. Developing nutrient profile models: A systematic approach. Public Health Nutr. 2007, 10, 330-336. [CrossRef]

111. Townsend, M.S. Where is the science? What will it take to show that nutrient profiling systems work? Am. J. Clin. Nutr. 2010, 91, 1109S-1115S. [CrossRef]

112. van der Walt, K. Thorough-Bread? A Study of the System of Provision of Bread in South Africa. Available online: http:/ / wiredspace.wits.ac.za/jspui/bitstream/10539/22221/1/Final\%20Masters\% 20Research\%20Research\%20Report\%2031\%20August\%20Katharina\%20v.pdf (accessed on 21 May 2019).

113. Gastrow, V. Problematizing the Foreign Shop: Justifications for Restricting the Migrant Spaza Sector in South Africa. Technical Report. 2018. Available online: https://www.africaportal.org/documents/18314/ Problematizing_the_Foreign_Shop.pdf (accessed on 21 May 2019).

114. Cooke, E.; Hague, S.; McKay, A. The Ghana Poverty and Inequality Report: Using the 6th Ghana Living Standards Survey, Technical Report. 2016. Available online: https://www.unicef.org/ghana/Ghana_Poverty_ and_Inequality_Analysis_FINAL_Match_2016(1).pdf (accessed on 21 May 2019).

115. Maluleke, R. National Poverty Lines 2018, Statistical Release. 2019. Available online: http:/ /www.statssa.gov.za/ publications / P03101/P031012018.pdf (accessed on 21 May 2019).

116. Smith, J.; Abrahams, M. 2016 PACSA Food Price Barometer Annual Report October 2016. Available online: https:/ / drive.google.com/file/d/1qva4R0wArjvU8HYCmHNLdqHHihhP8g-s/view? usp=sharing (accessed on 21 May 2019).

117. Anand, S.S.; Hawkes, C.; de Souza, R.J.; Mente, A.; Dehghan, M.; Nugent, R.; Zulyniak, M.A.; Weis, T.; Bernstein, A.M.; Krauss, R.M.; et al. Food consumption and its impact on cardiovascular disease: Importance of solutions focused on the globalized food system: A report from the workshop convened by the world heart federation. J. Am. Coll. Cardiol. 2015, 66, 1590-1614. [CrossRef]

118. Dixon, J.; Omwega, A.M.; Friel, S.; Burns, C.; Donati, K.; Carlisle, R. The health equity dimensions of urban food systems. J. Urban Health 2007, 84, 118-129. [CrossRef] 
119. Battersby, J. Beyond the food desert: Finding waysto speak about urban food security in South Africa. Geogr. Ann. Ser. B Hum. Geogr. 2012, 94, 141-159. [CrossRef]

120. Temple, N.J.; Steyn, N.P. The cost of a healthy diet: A South African perspective. Nutrition 2011, 27, 505-508. [CrossRef]

121. Faber, M.; Schwabe, C.; Drimie, S. Dietary diversity in relation to other household food security indicators. IJFSNPH 2009, 2, 1. [CrossRef]

122. Ahmed, A.U.; Vargas Hill, R.; Smith, L.C.; Wiesmann, D.M.; Frankenberger, T. The World's Most Deprived. Characteristics and Causes of Extreme Poverty and Hunger. Discussion Paper. 2007. Available online: http:// citeseerx.ist.psu.edu/viewdoc/download?doi=10.1.1.139.5305\&rep=rep1\&type=pdf (accessed on 21 May 2019).

123. das Nair, R. The internationalisation of supermarkets and the nature of competitive rivalry in retailing in southern Africa. Dev. S. Afr. 2018, 35, 315-333. [CrossRef]

124. Abrahams, C. Transforming the region: Supermarkets and the local food economy. Afr. Aff. 2010, 109, 115-134. [CrossRef]

125. Lindell, I. Informality and Collective Organising: Identities, alliances and transnational activism in Africa. Third World Q 2010, 31, 207-222. [CrossRef]

126. Li, T.M. The Will to Improve. Governmentality, Development, and the Practice of Politics.; Duke University Press: Durham, UK; London, UK, 2007.

127. Akinwumi, A. The Will to Transform: Nation-building and the Strategic State in South Africa. Space Polity 2013, 17, 145-163. [CrossRef]

(C) 2019 by the authors. Licensee MDPI, Basel, Switzerland. This article is an open access article distributed under the terms and conditions of the Creative Commons Attribution (CC BY) license (http:/ / creativecommons.org/licenses/by/4.0/). 